\title{
Music therapy methods, strategies and techniques for engaging children in meaningful music therapy encounters in hospital play therapy settings
}

Research Exegesis in partial fulfilment of the requirement for the degree of Master of Music Therapy

At the New Zealand School of Music, Wellington

New Zealand

Farhana Rizaini

2017 


\begin{abstract}
This qualitative study examines a music therapy student's practice on a paediatric ward in a general hospital in New Zealand. The study arose after I experienced challenges engaging and interacting with patients in a hospital play therapy setting, where patients stay was short-term. The research identified the music therapy methods, techniques and strategies I used to initiate and sustain musical interaction with them. Findings were generated from secondary analysis of two months' worth of clinical documentation and reflection. Both inductive and deductive thematic analysis was used to analyse the clinical data and reflection. The literature on paediatric music therapy, musical play and play therapy were reviewed. Findings are presented in two parts. The first section highlights the predominant music therapy methods I used: range of instruments, singing, use of props, listening, use of discussion and musical games; and the overlaps of strategies and techniques within. The second section identifies four main categories of music therapy goals to illustrate the unique and subtle differences of music therapy methods, strategies and techniques in relation to the goals. Subsequently, in the discussion section, findings are considered in the light of the literature, and limitations of the research are addressed.
\end{abstract}

\title{
Keywords
}

Music Therapy, Children's Hospital, Children's Ward, Paediatrics, Musical Play, Music Therapy Methods, Music Therapy Techniques, Music Therapy Strategies 


\section{Acknowledgements}

Dedicated to my late father, who would have been so proud of this milestone.

I would like to thank the following people who have made this possible:

My family, for the unconditional support, and belief in me and music therapy.

Friends who became family here, and the instant cheerleaders when I needed that 'push' to keep going. Friends back home as well for all the distance-based support!

Class of 2017: For journeying together $(-)$

Dr. Daphne Rickson, my research supervisor for all your wisdom, guidance and motivating me to always do my best. You are an inspiration!

Dr. Sarah Hoskyns for all your invaluable input and support in the last two years.

Andrea Robinson, my visiting music therapist for always being a listening ear and providing tips and tricks for placement.

Play Specialist at the children's ward for being such role models, advocates of music therapy and for overseeing my daily clinical work on the ward.

Children's Ward team for all the beneficial collaborative and multi-disciplinary work. Paediatric patients and their families for all the times music therapy has done its magic and for contributing to my research study. 
This research received ethical approval from Victoria University of Wellington, made on behalf of students in the Master of Music Therapy Programme. Application Reference: VUW Approval Number 22131, 15 th July 2015. 


\section{Table of Contents}

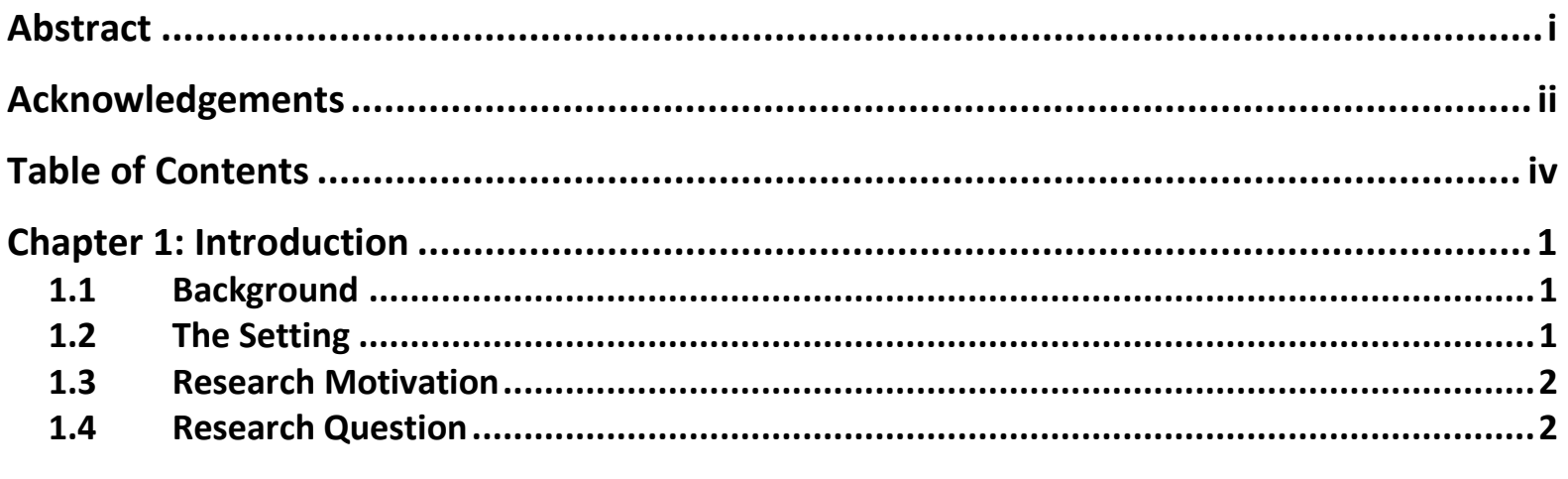

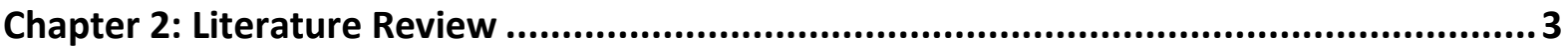

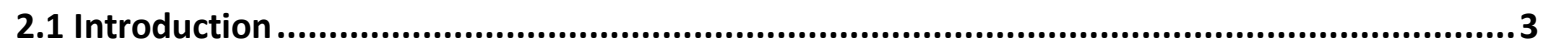

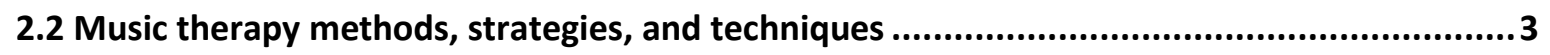

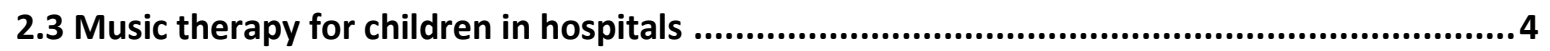

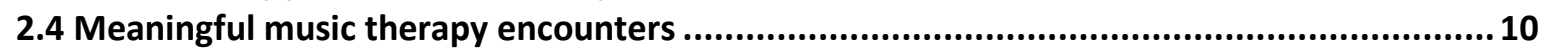

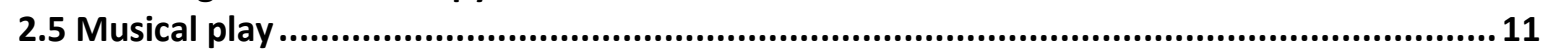

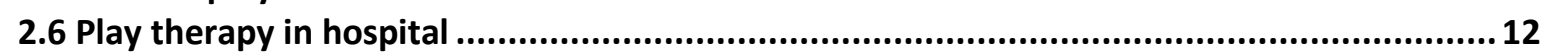

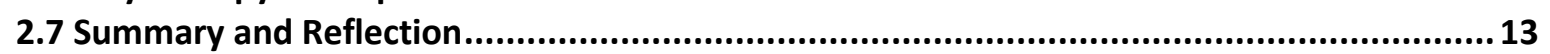

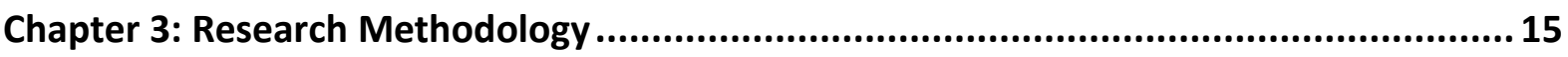

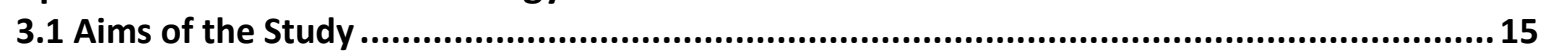

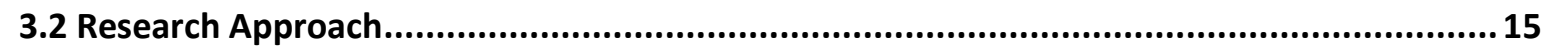

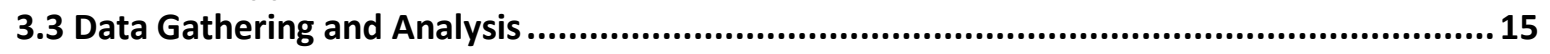

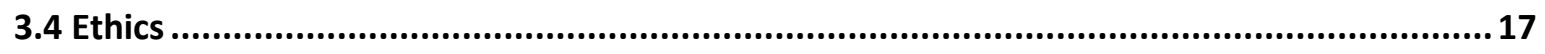

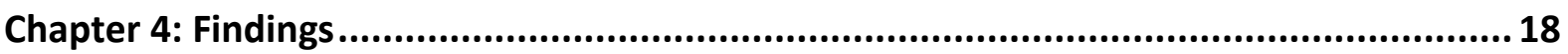

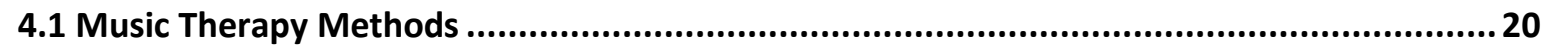

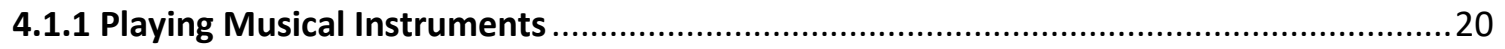

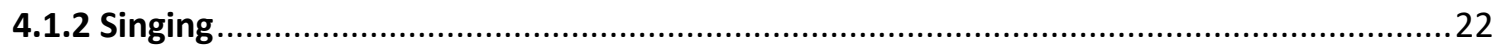

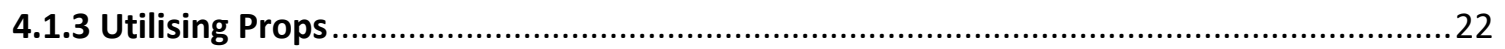

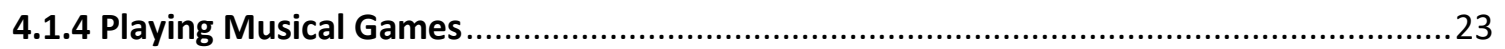

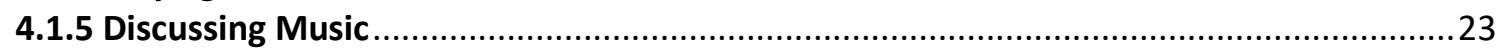

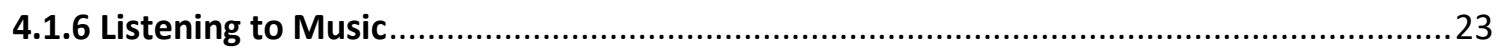

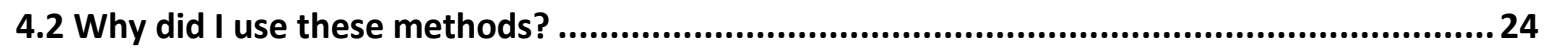

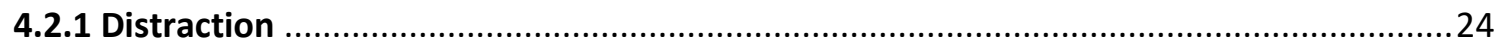

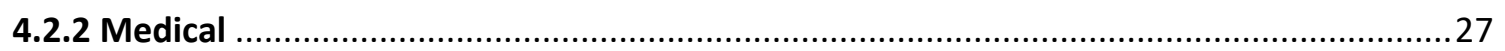

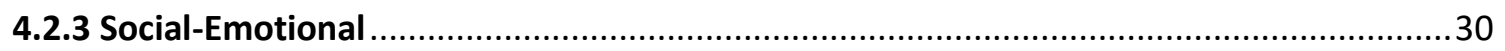

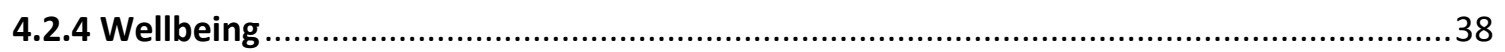

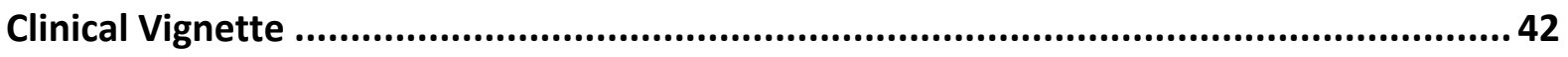

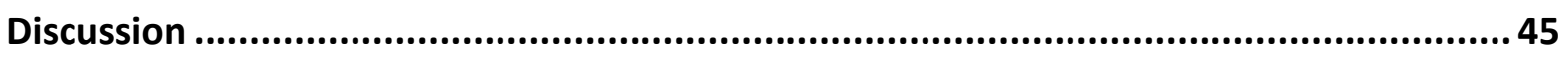

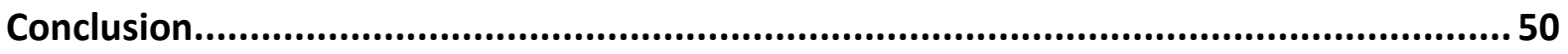

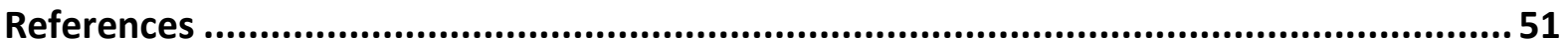

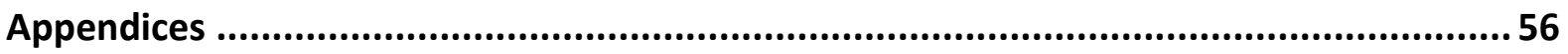




\subsection{Background}

\section{Chapter 1: Introduction}

This exegesis describes the music therapy methods, strategies and techniques of music therapy clinical practice I used at a paediatric ward within a general hospital. The work was undertaken as part of the Master of Music Therapy Degree at the New Zealand School of Music (NZSM). The clinical practice took place on a student placement over a period of eight months (approximately 750 clinical hours). Part of the work at the facility required working within a multidisciplinary team; where referrals could be made from anyone in the team. Patients could also self-refer. Research data consisted of clinical documentation and reflective notes from two months of this work which were analysed to uncover themes that are presented in the findings. Following this, a discussion developed from the findings is included.

\subsection{The Setting}

The facility I was assigned to was a paediatric ward within a general hospital, situated in Wellington City. Decorated with colourful mural paintings, the ward consists of eight single rooms for isolated patients and three big rooms with four beds each. The patients range from 0-14 years old. Diagnoses of patients and their individual needs varied greatly and the average stay of patients was one and a half days (shortterm). On a general paediatric ward, patients were being treated for various conditions including burns, physical injuries, asthma, bronchitis and mental health issues. Music therapy was usually conducted at bedside, in the playroom, or a treatment room within the ward. The playroom is an open space at the corner of the paediatric ward that's resourced with toys, games, instruments and materials that were easily accessible for children and their families. It was a particularly safe place for the children because no medical procedures took place there. Resources could also be taken out from the playroom and into the children's respective rooms. Since there was no music therapist working on site, I was supervised by a play therapist onsite as well as a visiting registered music therapist. 


\subsection{Research Motivation}

In a playroom or play setting where there is a lack of routine, children will naturally play with the numerous attractive resources available. Often, play may lead to or be part of music therapy sessions. I adopted a person-centred, humanistic approach in my music therapy work and which meant I usually began with what the children were interested in. However, I sometimes found it challenging as a music therapy student, to initiate and sustain musical interaction with patients in such an attractive and sensory-filled environment, especially at the beginning of my placement. Therefore, I was interested to find out what music therapy methods, strategies and techniques I could employ to engage children in a meaningful encounter in a hospital play therapy setting.

\subsection{Research Question}

What music therapy methods, strategies and techniques did I use to engage children in meaningful music therapy encounters in hospital play therapy settings? 


\section{Chapter 2: Literature Review}

\subsection{Introduction}

In this literature review, I will discuss five themes relevant to this research study. The search terms used included 'paediatric music therapy', 'music therapy methods, strategies and techniques' along with other terms that relate to 'musical play' and 'play therapy'. Other terms such as 'music therapy children's/paediatrics, hospital/ward' were also searched, as terms for this type of service can vary.

\subsection{Music therapy methods, strategies, and techniques}

Bruscia (2013) defined music therapy as an experiential form of therapy as the approach focuses on participants' experience of music. This is embodied within music therapy methods, strategies and techniques.

Methods: Bruscia (2013) defined method as "a particular type of music experience used for assessment, treatment, and/or evaluation" (p. 128). For paediatric patients, there is not one song, instrument, or music therapy method that can be applied to all (Neugebauer, 2012). Like other contexts, the four main methods identified in the literature as used by music therapists in a paediatric setting included a combination of receptive (e.g. listening), improvisational (e.g. instrumental play), recreative (e.g. lyric substitution, performing) and compositional (e.g. song writing) methods (Brooks \& O'Rourke, 2002; Bruscia, 2013; Neugebauer, 2012).

Strategies: Music therapy strategies or sometimes known as procedures, are "an organized sequence of operations and interactions that a therapist uses in taking the client through an entire music experience" (Bruscia, 2013, p.128). They are the underpinnings of music therapy sessions, where strategies are the numerous things a therapist does to accompany and implement methods (Bruscia, 2013). For example, strategies in a paediatric setting include call and response activities and conducting games to encourage interaction and control in a hospital environment where children may lack control (Ayson, 2008).

Robb (2003) developed a framework based on Jean Piaget's and Erik Erikson's child development theories that recommended music therapy strategies for specific age groups. Firstly, for infants and toddlers (0-2 years), it involved including parents and siblings in sessions, empowering parents by resourcing them with ideas and 
strategies they could use independently with their child, alleviate parent's anxiety by providing them with resources, facilitating interactions that maintain the parent-child bond, and using familiar, age-appropriate music and resources (Robb, 2003).

With pre-schoolers (2-7 years), music therapy strategies similarly included using familiar and age-appropriate music and resources, promoting patient-led activities to give choice, control and independence and giving patients an active role that is within their capabilities (Robb, 2003). After all, successful experiences that focus on what the patient can do may contribute towards self-identity, self-confidence and self-esteem (Neugebauer, 2012; Robb, 2003).

For school-age children, music therapy strategies include: encouraging and building on patients' development; especially related to abstract thoughts and cognitive coping strategies or self-expression (e.g. exercises or breathing activities structured by music), active music-making for pain management, singing, and involving parents and siblings (Robb, 2003).

Finally, adolescents are also admitted into the paediatric ward. Music therapy strategies for adolescents include tapping in and building on adolescent's advancing abilities in abstract thinking and problem-solving (e.g. teaching music assisted relaxation techniques), supporting relationships (familial and peers), supporting and building on adolescent's emerging interest and abilities (e.g. song-writing, music listening, music and art, lyric analysis) as forms of self-expression and active involvement (Robb, 2003, p.117).

A Technique, is defined as "a single operation or interaction that a therapist uses to elicit an immediate reaction from the client or to shape the ongoing, immediate experience of the client" (Bruscia, 2013, p.128). Therefore, techniques are the subtle interactions of the music therapist in the moment. Some examples stated by Bruscia (2013) include pacing, probing, and grounding.

\subsection{Music therapy for children in hospitals}

The literature on music therapy for children in hospitals was a mix of general and specific paediatric music therapy with patient specific diagnoses. It seemed that different presentations of various illnesses affect the music therapy interventions chosen. This is supported by Shoemark, Rimmer, Bower, Tuquet, Miller, Fisher, Ogburn \& Dun (2018) who identified that the medical status of the patient impacts 
how music therapy was implemented. Yet, most music therapy work from patientspecific diagnosis are also similarly utilized within the generic paediatric population. Some goals of music therapy for children in hospitals include providing emotional support for children and their families, facilitating rehabilitation, alleviating anxiety, assisting in pain management, procedural support, sensory and developmental stimulation, and socialization (Tucquet \& Leung, 2014). An overview of paediatric music therapy is presented in the subsequent sub-sections.

\section{Context and benefits of paediatric music therapy}

Shoemark et al. suggest that children's experience of music therapy during hospitalization serves as a motivator, positive reinforcement and a soothing agent (2018). The hospital environment can be a potential source of stress for children and their families as the unfamiliar and isolated environments, invasive procedures, and separation from family and friends are unavoidable realities of hospitalisation (Robb, 2003). Music is usually a familiar medium with positive connotations and connections for children, (Brooks \& O'Rourke, 2002; Edwards, 1999) and not associated with medical procedures (Stouffer \& Shirk, 2003). Music therapy is the intentional use of music by music therapist (Brooks \& O'Rourke, 2002) that "can be used in a variety of ways to help children deal with the myriad challenges of illness" (Turry, 2002, p.20). Music therapists can engage the child through positive musical and playful interactions by listening, feeling the sensations, moving to or creating music (Neugebauer, 2012). Music therapy can help hospitalised children reach developmental milestones, identify and express their feelings, re-establish a sense of control, cope with pain, anxiety and stress, engage with opportunities for socialisation, and improve overall wellbeing of the child and family (Ayson, 2008; Brooks \& O'Rourke, 2002 ; Hendon \& Bohon, 2008; Neugebauer, 2012).

Individual or group music therapy sessions with patients and/or families can take place in the hospital playroom, bedside, music therapy room or in other locations of the hospital and range from 15 minutes to over an hour (Neugebauer, 2012). Being flexible is important (Tucquet \& Leung, 2014) and as described by Lane (1996), one of the challenges of the music therapist in these settings is the requirement for an abundance of intervention ideas to respond immediately to patients at varying stages of illness, age, and developmental ability, as well as their families. As such, Lane (1996) notes that there may be instances when no music is utilized during music 
therapy sessions. Yet, this should not be considered as music therapy being unsuccessful as it is more important to proceed at a pace that is comfortable for the patient, and they may be drawn to the therapist before they are drawn to the music (Lane, 1996). This is supported by Robb (2003) who reiterates the client-therapist relationship as a factor to creating successful experiences, and the therapist as someone who can provide positive reinforcement, and be a familiar and supportive figure in the environment.

\section{Active music therapy and establishing rapport}

The research with hospitalized children differs from adults in that it focuses more on active music therapy; because children are people of action (Froehlich, 1996). This view is supported by Standley \& Whipple (2003) whose study on paediatric music therapy found that active music involvement was better than passive listening and live music was better than recorded music. Walworth (2003) also notes that live music interventions by music therapists can eliminate the need for sedation due to anxiety or noncompliant behaviour. When children are engaged in active music making, they are naturally motivated towards interaction, play, and engagement with their environment (Turry, 2002). Moreover, "through active music making and the therapist's conscious use of musical elements, initial rapport can be established and a child can feel heard and understood" (Turry, 2002, p.28). In contrast, Shoemark et al., (2018) identified that passive music listening through the use of headphones (for example) could be a means of creating personal space for the patient in a hospital context. Opportunities for creating personal private space could help the young patient feel comfortable. Thus, active music engagement and music listening, developmental musical play and therapeutic song writing are effective techniques aimed at reducing pain, anxiety and other issues (Neugebauer \& Neugebauer, 2003).

\section{Improvisational and procedural support}

Improvisation and songs are an avenue for patients to express thoughts and feelings and a means for therapist to likewise address patients' expressed concerns effectively (Turry, 2002). Brooks \& O'Rourke (2002) and Neugebauer \& Neugebauer (2003) suggest that depending on the child's developmental status, song writing with paediatric patients range from word substitutions to original compositions and can be adapted accordingly. 
In regards to procedural support, Neugebauer \& Neugebauer (2003) and Turry (2002) suggest that music therapy should ideally begin before the procedure begins and continue until the procedure has finished. In this context, music is used as a distraction which can reduce discomfort because the therapist redirects the patients' attention away from the stressful medical procedure or stimulus towards a nonthreatening stimulus i.e. music (Edwards, 1999; Sundar, Ramesh, Dixit, Venkatesh, Das \& Gunasekaran, 2016; Walworth, 2003). This is reiterated by Bishop et al. (1996) and Walworth (2003) who suggest that establishing rapport and familiarizing the patient with activities before the procedure resulted in a less traumatic transition for the patient and in turn, decreased anxiety. Improvisation is noted as particularly useful for pre-procedural, procedural and post-procedural support as it can complement and meet the sudden and frequent changing needs of the child (Turry, 2002). A study by Shoemark et al., (2018) likewise stated that the music therapist may offer a scaffolding structure of musical element-pulse, rhythm, tonality, timbre, to facilitate the patient's changing needs of the moment. Neugebauer \& Neugebauer (2003) argue that activities introduced prior to the procedure become normalised during the procedure and that the patient can find comfort and support from the music therapist and the now 'familiar' activities (Bishop et al., 1996). However, Edwards (1999) and Neugebauer \& Neugebauer (2003) emphasise the importance of recognising the individuality of patients, pointing out that a strategy that works for a patient may not work for another; and to recognize instances when another technique might be introduced or when to stop music completely.

\section{Use of instruments and movement}

To actively engage children in a non-threatening and developmentally appropriate activity, a variety of melodic and percussive instruments and interactive visual aids are used (Jarred, 2003). Children can project their hospital experiences on instruments (Brooks \& O'Rourke, 2002). Moreover, due to young children's short attention spans, the music therapists change instruments, songs and activities constantly (Walworth, 2003).

Instruments are also used to encourage movement. Instruments can be selected based on the movements specified by the physio and occupational therapist (Neugebauer \& Neugebauer, 2003). Music can also stimulate spontaneous movements (Marley, 1996) or generally motivate movement when its integrated into 
patient's rehabilitation sessions (Neugebauer \& Neugebauer, 2003). The music therapist engages children in purposeful activity rather than just physical routines (Neugebauer \& Neugebauer, 2003). Hence, the smallest movement, such as a wiggling finger, can be inferred as a rhythmic cue for a music improvisation, and a simple instrument such as chimes may be appropriate for the already offered movement (Izumi-Taylor et al., 2012; Neugebauer, 2012).

In addition to rehabilitation purposes, movement is also a means for young children to express their response to music because children can struggle to verbalise their emotional reactions to music (Izumi-Taylor et al., 2012). This idea is reaffirmed by Hair (1997) and Hendon \& Bohon (2008) who suggest that children naturally use movement and gesture to respond to music, to show how the music makes them feel. Elements of music that can be demonstrated through movement include "tempo, dynamics, accents, beat, patterns, meter, phrasing, form and style" (Hair, 1997).

\section{Use of familiar songs and family involvement}

The patient's musical-self that is ingrained in their musical heritage, uses of music, and current preferences, are at the core of music therapy in the paediatric setting (Shoemark et al., 2018). Authors cite the use of familiar songs for various reasons, one of which was for pain management, in which it was suggested that patient-preferred music may stimulate the body's natural painkillers and reduce the perception of pain (Lane, 1996). More commonly, it is cited to reduce children's anxiety, as familiar and enjoyable patient-preferred music could provide a sense of security, predictability and containment in an unfamiliar environment (Bradt, 2012; Brooks \& O’Rourke, 2002; Hendon \& Bohon, 2008; Jarred, 2003; Neugebauer \& Neugebauer, 2003; Stouffer \& Shirk, 2003). Nursery rhymes and finger plays are enjoyable and fun (Izumi-Taylor et al., 2012). However, Stouffer \& Shirk (2003) also emphasise that apart from just considering familiar, preferred music for reducing anxiety and promoting relaxation, the cultural context, past experiences with the music and the use of musical elements such as structure, dynamics and tempo are important factors as well. Regardless, a child's familiar and preferred musical material would be a quick way for a music therapist to establish a positive rapport with a child (Edwards, 1999).

With very young children or children who are unable to communicate their preferences, parents or caregivers can be a valuable resource for music therapists in 
terms of knowing the child's previous musical experiences, and what music the child finds calming (Stouffer \& Shirk, 2003). Stouffer \& Shirk (2003) emphasise the empowerment and inclusion of parents and siblings alongside patients, and encourage parent-child relations through interactions facilitated by the music and music therapist. However, Neugebauer \& Neugebauer (2003) noted that it is vital that music therapist adapt the therapeutic interventions according to the different needs, family dynamics and coping styles observed. While some parents avoid engagement with music therapy sessions in order to take time out, others might choose to participate (Neugebauer, 2012; Neugebauer \& Neugebauer, 2003). When they do choose to participate, the music therapist ought to involve parents according to their individual comfort levels and model appropriate ways to engage and interact with the child (Neugebauer \& Neugebauer, 2003). Sometimes parents can play an intermediary role, by interacting with the child and working alongside the music therapist (Brooks \& O'Rourke, 2002). Apart from families, sometimes music therapist have to infer patients' musical preferences through artefacts such as clothing (e.g. pyjamas that depict movie characters), or the toys that they are playing with (Shoemark et al., 2018). The use of patient's preferences, can create an intimate experience for both the patient and their families, if involved (Shoemark et al., 2018).

\section{Play and use of props within music therapy}

"Music may feel like play because music naturally enhances an environment of energy, life, joy and playfulness "(Izumi-Taylor et al., 2012). Sometimes, to engage the child, the music therapist has to integrate the child's nonmusical interests such as play into the session as a way to maximize their capabilities (Neugebauer, 2012). Including interactive visual aids (or 'props'), such as puppets or soft toys, can add variety and make an experience more meaningful (Brooks \& O'Rourke, 2002). Interactive visual aids often include puppets, soft toys, books, art materials, scarves, videos, costumes (Brooks \& O'Rourke, 2002; Jarred, 2003) and when incorporated into music therapy sessions, can maintain children's interest longer (Brooks \& O'Rourke, 2002). For instance, if the child has an interest in cars, songs can be composed or improvised based on cars (Brooks \& O'Rourke, 2002). Apart from the use of props to maintain children's interest, they can be used creatively in musical interaction. For example, wooden spoons make good drum or rhythm sticks, recycled pan lids can serve as cymbals (Izumi-Taylor et al., 2012) and objects such 
as tongue blades and syringes can be used as drum sticks (Brooks \& O'Rourke, 2002). Providing musical play enables the child to re-enact past experiences within a secure and non-threatening structure (Marley, 1996) and provide safety and comfort (Neugebauer \& Neugebauer, 2003).

\subsection{Meaningful music therapy encounters}

The term meaningful encounters involves two concepts; meaningful and encounters. Meaningful is defined as having a meaning or purpose and encounters refers to instances or experiences that come about especially unexpectedly (MerriamWebster, 2017). In a music context defined by Kenny (2007), "encounter suggests the depth in our experiences with music".

In music therapy literature, a more commonly known term related to meaningful encounters is 'meaningful moments' or 'meaningful experiences'. According to Amir (1996), the benefits of experiencing meaningful moments during music therapy has been reported to contribute to emotional and physical health. Amir's (1996) study of meaningful moments in music therapy described specific moments from the perspective of the music therapist and music therapy clients that were meaningful to one or both parties. She found that meaningful moments in the therapeutic process were transformative, spontaneous in nature, occurring at multiple levels and in multiple domains (physical, cognitive, and emotional), and were difficult to describe and measure. Other authors have gone on to illustrate their understanding of 'meaningful moments' or 'meaningful experiences' (Aigen, 2005a; Craig, 2009).

According to Aigen (2005a), one of the goals of therapy is to reduce the negative-related moments for patients and to find the right music that will keep participants engaged so that they will be medically distracted and become more involved in a meaningful activity i.e. music. Aigen (2005a) went on to describe meaningful experiences for a child as often originating when the therapist offers a containing musical form or structure which is not within the child's current capacity to create for themselves. For instance, creating improvisations or songs that reflects the child's current emotional state, can provide a vehicle for further expression.

On the other hand, a study conducted by Craig (2009) found that emotional responses to music are indicators of meaningfulness of music; in which multiple emotional reactions are associated with greater levels of meaningfulness. Barnes 
(2010) reiterated this when he described interpersonal exchanges with children as moments of meeting. Interpersonal interaction along with shared attention and communication were behaviours that led to the moments of meeting. These behaviours were listed as: (1) eye gaze; (2) affect/facial expression; (3) body movements/gestures/postures; and (4) sound-making through vocal/verbal expression. These are especially useful in a context where patients might have difficulty communicating the types of music that are meaningful for them.

\subsection{Musical play}

"Musical play is a common feature of young children's experiences in music in the early years of life" (Koops, 2012). Play constitutes a fundamental element in a child's life; and music is a common part of young children's play (Niland, 2009). Marsh \& Young (2006) defined children's musical play as everyday forms of musical activity where children independently initiate activities or choose to participate with others voluntarily. While musical play can be age-specific and context dependent, there are certain characteristics of musical play that persist across all ages: which are always spontaneous (Marsh \& Young, 2006; Niland, 2009), multimodal, and improvisational (Marsh \& Young, 2006). Niland (2009) noted the importance of child-centred musical play, suggesting that following children's interests empowers them to have a greater interest in music-making. This was supported by Tarnowski (1999), who suggested for adults to respect the rules for musical play created by children, and not impose their own ideas on the musical situation.

Koops (2012) research highlighted some examples of musical play, such as "playing a set of pots and pans as a drum set, singing while playing with dolls, dancing at the breakfast table to recorded music, and marching around the house with rhythm sticks and tambourines in a pretend parade". Moreover, musical play and movement related activities include vocalisation: chanting, singing, imitating, rhythmic movement: rocking, patting, touching and moving (Izumi-Taylor, Gunn Morris, Meredith, \& Hicks, 2012; Tarnowski, 1999) and playing instruments (Tarnowski, 1999). Some examples of musical games include: Hoki Toki, Pop Goes the Weasel, If You're Happy and You Know It, Ring Around the Roses, Musical Chairs and Duck Duck Goose (Izumi-Taylor et al., 2012). 
Engaging in musical play can increase children's musical skills (Niland, 2009) and provide social (Marsh \& Young, 2006; Tarnowski, 1999), emotional, and cognitive benefits for the holistic development of a child (Tarnowski, 1999).

\subsection{Play therapy in hospital}

Music therapy and play therapy in hospitals have similar purposes. In particular, both enhance the child's sense of normality within the hospital setting (Hendon \& Bohon, 2008). Play is enjoyable, self-directed, spontaneous and voluntary; (Bishop, Christenberry, Robb \& Rudenberg, 1996) and children can reconstruct the world in a way that is understandable to them (Kneisley, 1996). It is an integral part of every child's life (Kneisley, 1996). "When play is used for therapeutic purpose it is called play therapy," (Khurana, 2000, cited in Vijaya, 2014) and hospital play therapists' goal is to help paediatric patients adjust and cope with hospitalisation (Kneisley, 1996). Therefore, for a sick child, play therapy is more than recreational play. Rather, play in the hospital setting serves a number of purposes, including maintaining routine, providing a means of distraction, a way to address concerns, a means of facilitating a smoother adjustment to the unfamiliar and potentially frightening admission to hospital, (Doverty, 1992 ; Vijaya, 2014). It also offers a form of self-expression to help alleviate and cope with stress and anxiety (Doverty, 1992; Jun-Tai, 2008; Marley, 1996; Vijaya, 2014). Play provides comfort and reassurance through enabling children to have control over situations or experiences in which they feel vulnerable (Jun-Tai, 2008; Marley, 1996).

Due to the unpredictability of the setting, play therapists (sometimes known as play specialists) are adaptable and quick thinking as they often have little time to plan (Knight \& Gregory, 2009). Play therapists work as part of a multidisciplinary team to contribute to the care provided to the child and families in clinical environments (JunTai, 2008; Knight \& Gregory, 2009) and their success is dependent on the willingness of the multidisciplinary team to collaborate with them (Knight \& Gregory, 2009) The roles of a hospital play therapist include organising daily play and art activities in playrooms or at bedside, providing play opportunities to achieve developmental goals, helping children cope with anxiety, using play techniques to prepare children for procedures (Jun-Tai, 2008), supporting children's families and siblings, contributing to clinical judgements through play-based observations, educating other staff on the 
value of play for sick children, encouraging the development of peer-group friendships and organizing parties and special events for children in hospitals (National Association of Hospital Play Staff, 2000, cited in Knight \& Gregory, 2009). In the absence of a play specialist, other medical staff can also be taught basic play skills, though the play specialists must be clinically trained (Knight \& Gregory, 2009).

Apart from the purpose of therapy, play is also a diagnostic instrument (Marley, 1996; Vijaya, 2014) where the selection and rejection of play material carry significant meaning. This is a means of communication; which is the key to coping (Brooks \& O'Rourke, 2002). As exemplified by Doverty (1992) and Jun-Tai (2008), children may non-verbally communicate specific information through play such as painting, sculpting or dolls which could reflect their present level of understanding of their predicament. Thereafter, structured interventions and directed play may assist the child in their understanding of medical procedures and increase their cooperation and coping strategies in relation to treatment, choice and consent (Jun-Tai, 2008).

Play could also contribute to medical interventions where recovery could be made fun when play is incorporated as part of the recovery process (Doverty, 1992). Examples include blowing bubbles, whistling or blow painting to aid respiration. This positively reinforces medical goals and facilitate a quicker discharge.

\subsection{Summary and Reflection}

The task of initiating therapeutic encounters or beginning and sustaining musical interaction with children who are engaged in other forms of play, or who do not feel like playing at all, is complex. However, through songs, play, movement, and games, the music therapist can enter the child's world (Brooks \& O'Rourke, 2002; Froehlich, 1996; Hendon \& Bohon, 2008). Jarred (2003) summarises the clinical recommendations for paediatric music therapy, where music therapist should use live music whenever possible, engage in interactive and stimulating music therapy, use patient-preferred music, facilitate musical preoperative education, relaxation techniques paired with music and psychological preparation. Thus, as suggested by the literature review, I am likely to employ a wide range of music therapy methods, strategies and techniques which vary according to children's individual presentation which in turn is affected by the interaction of their personalities, medical conditions, and current emotional state. By engaging in secondary analysis of my clinical data, I 
will be able to articulate the multitude of music therapy methods, strategies, and techniques that I employed and to contextualise them in ways that will be informative for other music therapy students and music therapists. 


\section{Chapter 3: Research Methodology}

\subsection{Aims of the Study}

In seeking to answer my research question 'What music therapy methods, strategies and techniques did I use to engage children in meaningful music therapy encounters in hospital play therapy settings?' I formulated the following aims:

- to link the music therapy methods, strategies and techniques proposed by other music therapists in paediatric settings with my own practice

- to share my findings of the music therapy methods, strategies and techniques I discovered out of my own practice and contribute to the body of paediatric music therapy and to other practitioners who would be particularly interested in music therapy within hospital play therapy settings

\subsection{Research Approach}

While there is sufficient evidence of paediatric music therapy literature that could guide music therapy practice within a play therapy setting, the research question arose out of my concern that it could be difficult to initiate and sustain musical interaction with patients in a hospital play setting-where the short term nature of the work and open environment is a personal challenge. Thus, as mentioned in the aims of the study, I sought to find out the music therapy methods, strategies and techniques I would use to initiate and sustain musical interaction with children in music therapy within a play therapy setting.

\subsection{Data Gathering and Analysis}

Data was collected from clinical notes and reflections that were written as part of my routine student music therapy practice. Clinical notes refer to the observational notes written after a music therapy session with a patient while reflection refers to my own personal thoughts and reactions or concerns regarding the work. For this reason, secondary analysis of data was adopted as secondary analysis of data is a method which uses data that already exists (Campbell, 2007). Consent was granted by the facility, to re-examine the clinical data to answer my research question. Two months of clinical documentation and reflective data i.e. April-May 2017, was utilised since after that I was uncovering similar findings (i.e. I had reached the saturation point). 
The data contains information about the music therapy methods, strategies and techniques I used to engage children in hospital play therapy settings. As the naturally occurring raw data (i.e. descriptive notes) is rich, it lends itself well to thematic analysis. The aim of using thematic analysis, in conjunction with secondary analysis, was to review past data to "identify, analyse and report patterns (themes) within data" (Braun \& Clarke, 2006, p.79). I primarily used deductive thematic analysis because I already knew what I was looking out for (Lapadat, 2012). Thus, music therapy methods, strategies and techniques became my codes.

Later, I engaged in inductive thematic analysis, which is a more typical approach of thematic analysis (Lapadat, 2012), to code new patterns. The six phases of inductive thematic analysis include: familiarisation with data, generation of initial codes, searching for themes among codes, reviewing themes, defining and naming themes, and producing the final report (Braun \& Clarke, 2006).

The following steps were taken in the data analysis process, drawing on procedures described by Braun \& Clarke (2006) and Lapadat (2012); with the research question in mind.

1. Deductive analysis: I read the clinical and reflection notes carefully and picked out brief, significant content that were relevant to the research question, and gave them an initial code. I then categorized them into broad themes of goals, music therapy method, strategy, and technique that were relevant to the research question (see Appendix 3.1 \& 3.2).

2. Inductive analysis: I read the clinical and reflection notes again and reviewed and analysed the initial raw coding of data within themes to establish new categories (i.e. codes under music therapy methods, strategy and technique). I constantly looked back to interpret and make sense of the 'old' and 'new' categories to make sure they represented the raw data well.

3. Deductive and inductive analysis: The last step I did was to review the themes and categories and further categorized the data by grouping similar goals together, followed by the music therapy method within each goal (see Appendix 4). I decided to sort the data by goals to illustrate the findings from data. I chose this method as it seemed logical that I would be utilizing different methods, strategies and techniques to achieve different goals. 


\subsection{Ethics}

I adhered to the Code of Ethics for the Practice of Music Therapy in New Zealand (New Zealand for Society for Music Therapists, 2006), and the code of ethical conduct for research, teaching and evaluation involving human participants by Victoria University of Wellington (Victoria University of Wellington, 2016). Ethical approval was granted to Daphne Rickson, Senior Lecturer and Sarah Hoskyns, Director of Music Therapy to supervise low risk projects such as those involving secondary analysis of data (VUW Approval Number 22131, $15^{\text {th }}$ July 2015). Additionally, the following steps were taken.

- Information sheets and consent forms were prepared for the facility.

- Information and consent forms were prepared for patients, families or staff who may be identifiable in the data, and to request permission to include a vignette.

- Any identifying information in relation to participants or facility was changed.

- Research data stored on the computer was password protected.

- On completion of the study, data will be stored securely at Victoria University of Wellington for a period of 10 years after the research has concluded at which point it will be safely destroyed.

- Upon completion of the research, summaries of the report will be disseminated to the facility. 


\section{Chapter 4: Findings}

This study aimed to uncover how I initiated and sustained music therapy interaction with patients in an attractive and sensory-filled playroom in a hospital play therapy setting and the music therapy methods, strategies and techniques I used to keep them engaged. As I was analysing the data, I was reminded that the methods and strategies I uncovered were chosen according to my music therapy goals. The methods and strategies are what I did and the techniques explain how I did things; while the goals (or purpose of music therapy) describe why I did what I did. That said, there were many other factors (including the context of the therapy, the personality of the child, the presence of other people and so on) that meant various methods and strategies could also be employed to meet similar goals.

Findings have therefore been presented in two parts. In the first section, I have presented my findings according to the predominant methods, with strategies and techniques that I used, alongside broad (relatively common) information about 'why' I used them (my goals). In the second section, I have presented my findings according to therapeutic purpose (music therapy as distraction, music therapy to facilitate medical outcomes, music therapy to encourage social-emotional opportunities and music therapy to improve wellbeing), to demonstrate how I needed to adjust my strategies and techniques within music therapy methods in unique and specific ways to suit the therapeutic purpose. My overall finding is that engaging children in music therapy in a hospital setting involves taking a playful, flexible approach. 


\section{Overview of Findings-Music Therapy Methods}

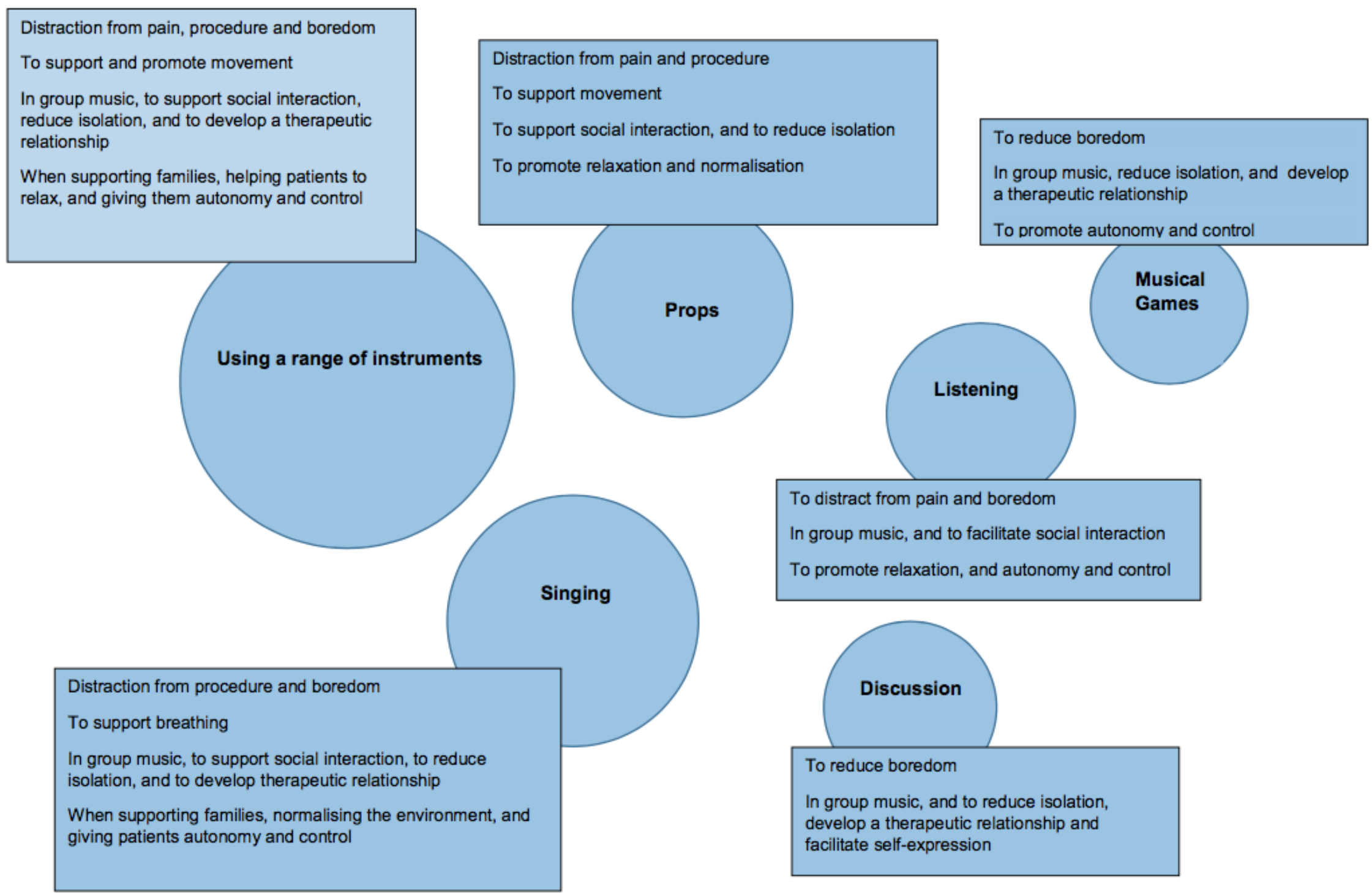

Figure 1: Overview of findings (Music Therapy Methods) to answer the research question

Note: Circles not drawn to scale 


\subsection{Music Therapy Methods}

The circles in Figure 1 highlight the predominant music therapy methods I employed to engage children in meaningful music therapy encounters in hospital play therapy settings (playing instruments, singing, using props, listening, discussing music, playing musical games). The rectangles highlight the goals I was holding in mind as I engaged children in music therapy.

In the paragraphs below, I begin with an overview of each of the six predominant methods that I used. Then, I focus on each of the four predominant goals that I was holding in mind (Distraction from pain, procedure, or boredom; Medical Treatment, e.g. the promotion of movement and respiratory function; Social Emotional Wellbeing, e.g. social interaction and the reduction of isolation; and more general Wellbeing goals including the development of a therapeutic relationship; the facilitation of self-expression; enhancing family relationships; encouraging feelings of relaxation and/or normalisation; and the promotion of autonomy and control).

\subsubsection{Playing Musical Instruments}

I used a wide range of musical instruments in my practice. Some instruments were familiar to patients and it was normalizing for them to encounter them in the hospital setting. Additionally, some patients or siblings had some musical skills on tuned instruments. When I played on instruments or introduced instruments to patients in individual or group settings, they were motivated to interact with me. Some sessions could start out as a 'jam' and parents could be encouraged to join in or lead. Patients would often develop the confidence to lead an activity. Most times, the instruments we engaged with would be patient-selected, and the role I played in the session depended on their choice of instrument for me as well. Resource booklets, song board charts and sheet music helped to prompt or guide the interaction. Usually giving patients an instrument to hold would eventually lead to them playing it.

Patients became fully engaged when playing instruments, and this distracted them from uncomfortable or distressing things that happening around them. Having a variety meant that new instruments could be introduced to re-capture patients' interest, and help them manage boredom or a stressful environment.

For children with physical injuries or for those who were not motivated to move, instruments were a source of motivation, as patients would reach out to sound them. 
I had to make sure instruments could be easily accessed and sounded, but patients would also respond to a challenge to move in particular ways to see or play musical instruments. Patients with special needs particularly, were stimulated by the sensory and tactile feedback that instruments provided. Stimulation through feeling the vibrations from instruments often had patients' moving and increased their sense of body awareness.

When instruments were readily accessible patients and siblings were seen to explore, and to naturally weave between music and other toys. Having a variety of instruments to explore often led children to creative pretend play, playful improvisation and musical games. I would join in by modelling ways to play instruments, exploring instruments' timbre, singing (over the top, improvised, vocal sounds), imitating or playing contrasting rhythmic patterns, sharing the playing of the instrument in a turntaking manner or picking up on patients' musical cues to extend their lead. The instruments created a connection between us.

The boomwhackers were particularly popular amongst patients and they would often bring them over to me. I encouraged patients to play by joining their creative exploration. Some patient-led exploration included pretend play, tapping the tubes against other objects and vocalising through one end.

When patients were already playing on a tuned instrument, I would initiate interaction by sharing the playing of the instrument, accompanying on other instruments, following their lead. Meaningful moments were observed as they began to follow my lead, to sing with me or to play family tunes.

Patients were motivated to go the keyboard that was set up in the playroom. Some patients had keyboard skills, and I observed lovely moments of connection when I selected appropriate sheet music for them to play and accompanied them with chords in the left hand. At times, patients would request songs that I had no sheet music for and I would notate it for them to encourage continued music-making. Other patients with no musical training could still play melody on the keyboard as I guided them through sheet music with alphabet notations. Regardless of the ways they accessed the music, most patients enjoyed exploring and improvising with me on the keyboards' automatic features.

Patients and siblings were also often attracted to the guitar. Children who had prior experience with the instrument, would respond to my encouragement to perform 
i.e. play and sing. Sometimes they played spontaneously. Using the iPad, I could introduce other familiar songs with similar chord progressions.

On the other hand, patients and siblings who had no experience with the guitar, still engaged with it by strumming open chords to familiar songs. Some also asked me to teach them how to play the guitar. I would then demonstrate and teach simple chords and strumming patterns or plucking.

The guitar and ukulele were sometimes used together. The shape of the guitar often encouraged children to pick up the ukulele to imitate me, and vice versa. When patients were on the guitar or ukulele, I would sometimes use the other to guide them to play a steady beat and model strumming.

\subsubsection{Singing}

Singing was a part of daily life and a familiar activity for most patients. Sometimes patients, parents, or siblings led singing sessions as they spontaneously broke out into song or were already singing when I joined in. At other times, I facilitated patients and their families in singing potentially familiar songs or favourite songs. Song selections were either suggested verbally by myself, parents, or patients; or through the use of resources such as a song board chart listing popular songs. In instances where patients had to be encouraged to join in singing, I used pauses, echoing, turntaking, spaces to 'fill-in-the-blanks', provided options of verses to choose from, slowed down at the end phrases, and varied dynamics. Pre-recorded music could also invite singing. At times the music naturally had patients mouth the words to the music, before joining in on the sing-along.

\subsubsection{Utilising Props}

The things that patients were interested in at any given time, or familiar items that were comforting for children, were used as props. Props enabled me to make a connection and interact with patients through improvisation or adapting familiar songs using the props. I also introduced props alongside music to encourage movement with patients or to bring groups of people such as families together. For patients with special needs, the used of sensory-based materials with music would provide tactile feedback. 


\subsubsection{Playing Musical Games}

I would engage patients in musical games through the use of a range of instruments, technology-based games, and music resource sheets. In individual and group settings, patients would often collaborate with me to invent musical games and provide input for play rules, which was empowering and would allow them to anticipate what would happen. Some common play rules involved negotiating the sequence of the game, manipulating musical elements and 'scoring' systems.

\subsubsection{Discussing Music}

Knowing what patients liked, and what was familiar to both of us helped to develop the therapeutic relationship. I would engage patients or caregivers in verbal discussions to find out about patients' musical interests and skills which would assist with planning, and to find out who might want to join them in group sessions. The use of technology as a focus for our discussion enhanced our communication. I also engaged patients in discussion when we were developing lyrics for song writing.

\subsubsection{Listening to Music}

Listening to live music or pre-recorded music was another method in my practice. I gave patients the choice to listen to music while engaged in other activities, and provided soothing music to support or encourage parents and their children to relax through movement. Sometimes we listened to music as a focus for ongoing discussion; or as a preliminary activity leading up to more active music making. When I was running group music, visitors to the group could be involved in listening to what other people were playing or singing, and thus be included. Sometimes too, patients would request to listen to their own music with me. 


\subsection{Why did I use these methods?}

The music therapy methods, strategies and techniques that I used in a paediatric setting depended on the music therapy goals that I was working on. I therefore also sorted my data according to these goals, and these are presented here in the second part of the findings.

\subsubsection{Distraction}

Children in hospital often needed to be distracted from pain, soreness, daunting procedures, or boredom. Music can provide a distraction - albeit temporary - for patients, resulting in staff members to perform their job much more easily.

\section{Playing Musical Instruments}

A range of instruments could engage patients to the point they might forget they were in pain. Having their hands full could stop patients from scratching, by encouraging them to use their arms, as they attempted to sound instruments. I also used a song board chart, resource booklets, sheet music, and accompaniment with voice, guitar and ukulele. For example, my guitar and vocal accompaniment encouraged one patient to play a steady beat on a range of instruments. Another time, when I was playing on the ukulele, a patient took the guitar and strapped it over herself while singing along. Once I collaborated with a patient to create a percussion set out of hand drums, tambourine, triangle and castanet. When a rhythm got going, the patient started humming and I was then able to extend on their lead by introducing ostinato patterns.

Exploration of the range of instruments often led to playful improvisation and musical games. I would share the instruments by tapping or modelling playing another piece of the same instrument to encourage patients' participation. I might offer new instruments when a patient seemed disinterested. I would improvise lyrics to match the exploration, share the playing of the instrument or pick up on patients' musical cues such as a single tap on an instrument to signify 'play'. For example, a rhythm game and musical conversation might emerge as I played within patients' space, imitated their rhythmic patterns or vice versa.

Particularly, when sharing drums (or carousel bells) together, we would sometimes play turn taking games or 'stop and go' games. I would use anacrusis and 
tempo changes for example to help patients anticipate 'stop'. When we played simultaneously on the drums, I would play a contrasting rhythm to keep the child engaged.

Patients and siblings were often attracted to the guitar. For those who had prior experience with the instrument, they could be encouraged to 'perform' (play and sing) for others in the playroom. To support their 'performance', I might play rhythmic accompaniment on another percussive instrument and join in singing or facilitate group singing with others in the playroom. On the other hand, patients and siblings who had no experience with the guitar could still engage with it by strumming open chords as we sang familiar songs. Sometimes patients and siblings requested for me to teach them how to play the guitar. I would then teach them simple chords such as G, D, and A. To further support their learning, I would check patients' and siblings' fingering and suggest positions that could be more comfortable to sound the chord. In instances when chords were too difficult for patients and siblings to manage, I would alternatively introduce songs with ostinato patterns. 'Love Yourself' by Justin Bieber, for example, could be played by just plucking the bottom E string on the guitar.

The shape of the guitar often encouraged children to pick up the ukulele as I was playing potentially familiar songs. Even when they seemed unenthusiastic about playing, they might be encouraged to pick up their "little guitar" to imitate what I was doing. The use of pauses would encourage patients to sing. Sometimes the reverse was true. A patient who could play guitar chose for me to accompany him on the ukulele and I followed his pace as I sung over the top. He was able to choose and lead the song, and during moments when he didn't know the chords, he was able to maintain an appropriate strumming pattern. Other times, when patients were on one of the instruments (guitar or ukulele), I could use the other to guide them to play a steady beat and model when to change chords. This seemed to help patients as they would eventually play more confidently and could at times join in singing afterwards. Thereafter, we could then look up for other familiar songs with similar chord progressions on the iPad.

When patients chose the keyboard, we were able to use the automatic features (with me joining in on the exploration) such as the 'percussion kit' feature. This was attractive and easier for some patients to manage, especially when they were in a compromised position. For example, when one boy had his arm in a sling, I could play floor tom and snare on particular drums (keys) and the patient could supplement with 
hi-hat beats with his good hand. Other times, I could also help patients play melody on the keyboard by guiding them to simple sheet music and pointing and humming along to the tune as they played.

\section{Singing}

It was not always possible to keep patients calm but often they could be distracted by singing during medical procedures. Creating a musical environment with nurses joining in singing patients' favourite songs were an effective distraction during procedures. Other times, strategies such as 'fill-in-the-blanks' or following patients' singing lead encouraged patients to sing instead of focusing on the procedure. For example, one patient chose 'Twinkle Twinkle Little Star' specifically for when his blood was getting drawn. I plucked on the guitar as accompaniment to his singing. When patients or siblings independently broke out into song, I would acknowledge by listening or attempting the accompaniment on an instrument. Other times, I might encourage patients to share their music by singing, utilising the song board chart, or initiating a potentially familiar song. The use of musical elements such as slowing down and pausing often encouraged patients and siblings to join in.

\section{Utilizing Props}

To distract patients from pain, it seemed important to focus on what they were interested in at that moment. When I wanted to distract them during medical procedures, familiar items were comforting. I would make a connection with patients through improvisation or adapting familiar songs to patients' toys. For example, when a patient was blowing bubbles, I adapted the bubble song by using anacrusis within the song and provided an accent on the beat when the bubbles appeared and/or in time with the patient popping the bubbles. In another example, when a patient played with the toy car, I created sound effects and hummed along to the pre-recorded tune that was playing from it.

\section{Playing Musical Games}

Musical games could involve instruments (e.g. piano), technology (e.g. drum application on the iPad) or resource sheets (e.g. Alphabet game). We could play the games in a turn-taking manner, coming up with the play rules or allowing patients and 
siblings to partner up with each other, myself or the play specialist if they were reserved or seemed to have difficulty in engaging with the musical games.

\section{Discussing Music}

Discussions were sometimes used to find out patients and their siblings musical abilities or musical preferences. If they played any instruments, I could suggest songs they could play at their skill level. For example, one time, discussion of music and songs led to the set-up of a sibling group where we then shared songs in a turn-taking manner.

\section{Listening to Music}

Sometimes, listening to live music was all that was required to distract patients during medical procedures. Being able to play live music meant that I could match music to the present moment and improvise when necessary to suit what was happening. The concept of time was lost as music took over the duration of the procedure. For example, with guitar accompaniment, I matched what was happening with a song the patient knew - 'Let It Go' while the nurses removed a medical line. Another time, when the nurses had to apply pressure on the site of removal, I extended patients' favourite songs by repeating the chorus to match the specific time needed to complete the procedure. It also seemed that when nurses enjoy listening to the music, the patients would as well. As quoted by a nurse, "It's so nice to just sit here (next to patient) and do this (sway)".

When I was unfamiliar with songs that patients shared, we would use technology (iPad) to listen to music together. Additionally, the iPad could also be used as a means for patients to select the next song from the suggestions list on YouTube.

\subsubsection{Medical}

Music was used to encourage movement and to improve breathing. I worked with the multidisciplinary teams' goals. Patients with special needs, post-surgical, or other medical conditions (such as diabetes) were required to be mobilized as part of their rehabilitation process. Music can benefit patients with respiratory diagnoses such as asthma. Singing particularly was utilized to improve breath control. 


\section{Playing Musical Instruments}

The keyboard, situated in the playroom, could motivate patients to walk over (on crutches sometimes) or stand independently for a moment to play it. I would then join in on the exploratory improvisation on the keyboard.

One time when I played the guitar, it motivated a patient to use her affected arm to imitate my strumming pattern. Stimulation through feeling the vibrations from the guitar also encouraged movement. As I placed patient's hands over the vibrating body of the guitar, she reached out with one finger to play the strings. I mirrored her offered action by using one finger to strum as well and guided her finger to play.

Especially for patients in a compromised place, accessibility was important. Wrist bells for example would mean that any subtle movement patients' make would sound the instrument. I could also place instruments closer to either side of patients' hands to encourage them to reach out and sound instruments as well. To further enhance motivation, I would sing familiar songs, facilitate their movement, stimulate their hands by stroking instruments against them, demonstrate the sounding of the instrument, or play an accompaniment on another instrument.

In particular, drums, shakers and tambourines, accompanied with vocal glissandos were used for directional movement for patients to track. They were also used for tactile feedback and body awareness as I could tap against their body parts. For example, I gently tapped the drum and tambourine against a patient's clenched fist and sang 'Aiken Drum' which had a ti-ti-ta rhythm.

Sometimes it was useful to work alongside other staff to encourage movement. While the staff facilitates the playing of instruments with patients, I could further support the musical environment by playing accompaniment. For example, I matched the play specialist and patient's quick shaking with the same intensity of strumming on the guitar.

\section{Singing}

For patients with respiratory conditions such as asthma, singing could help improve, or monitor breath control. In some instances, I might even explain the benefits of singing to these patients. Whether patients were aware of my therapeutic goal or not, they were able to sing without noticeably looking or feeling breathless. 
As patients were encouraged to sing or join in singing, it was important to sing songs which patients were familiar and comfortable with. At times, patients might start singing spontaneously or, to encourage participation, I would lead the song in a 'call and response' manner. Other times, it was helpful to have a discussion first so that I could make a list of patients' familiar songs. I would also use the song board chart or pick up on cues that patients were giving (such as doing the actions for the next verse, or picking up an animal that we would sing about next). We might also accompany ourselves by playing percussion instruments to the beat.

\section{Action Songs}

When patients had special needs, action songs could encourage their body awareness as they participated in finger plays, mirrored the actions or movements. Sometimes it was useful to begin sessions with action songs first. Thereafter, the patient might move more independently to play instruments when introduced. For example, when a patient held my hands in a palmer grasp, I offered maracas in place of her grip on my fingers. The use of dynamics and tempo within the actions had her responding with a chuckle.

On the other hand, patients with physical injuries might attempt to imitate the actions or offer movements in their compromised situation so that I could adapt into the framework of action songs. For example, one patient wiggled toes in which I adapted into an action song 'If You're Happy'... "wiggle your toes".

\section{Utilizing Props}

Props such as bubbles, figurines and parachute; accompanied with music, were very effective for motivating movement. When I supported using musical elements such as tempo (slowing down at the end of the phrase), patients could anticipate when to do certain actions or movements with their props, such as giving the parachute a higher toss. One time, I worked alongside the physiotherapist and introduced props and music into the physiotherapy session to motivate a patient to jump (physiotherapy goal: increase heart rate). As the parachute moved up and down with items bouncing on it, the patient was naturally encouraged to jump. I matched a familiar tune 'Pop goes the Weasel' to the shaking of the parachute and the patient's rhythmic jump as well. 


\subsubsection{Social-Emotional}

In a hospital setting where patients are often isolated and need an avenue to express their feelings or thoughts, supporting their social and emotional wellbeing was important.

Sometimes patients were engaged in solitary play on instruments or toys despite being in the playroom. From time to time, some patients also seemed keen to engage as they passed instruments or toys to me. Group music could be introduced so that patients could socialise with others. However, depending on patients' diagnoses, some children would be placed in isolation rooms, or were under bed rest orders. Other times, a couple of patients were simply not interested in being in the playroom. In these situations, music therapy was conducted at the patient's bedside to improve their social-emotional wellbeing.

While the therapeutic relationship is at the core of what I did in all circumstances, I needed specific strategies to connect with some patients. For example, when they were not keen on music initially or I had difficulty in finding out their musical preferences, I would engage them in verbal interaction, making up and playing musical games, or singing together. The strategies included the use of familiar songs, resources (e.g. iPads and song board chart), discussions (direct questioning), collaborating and negotiating ideas with patients.

\section{Playing Musical Instruments}

When patients and their siblings were playing with toys individually in the playroom, music was a means to bring all of us together. The accessibility of instruments (scattered around the playroom) would naturally encourage exploration. Patients and siblings naturally weaved between music and other toys. To support patients' exploration as they encountered instruments, I would sing with accompaniment (improvised, favourite songs), offer instruments, model the playing of the instrument, share the playing of the instrument or encourage with a nod when we made eye contact. Sometimes patients were the ones who invited other children to join them in the music making. At times, negotiation was necessary when two patients wanted the same instrument. When they were present, parents could start off the session by playing on instruments as they could help make the connection between patients and myself. While I accompanied parents in singing their child's favourite 
songs, their children would eventually pick up an instrument and join in or parents might guide their child's hands to sound instruments. The musical environment generally encouraged exploration of instruments, singing and dancing even though children were engaged in something else.

When patients were already playing on an instrument, I would initiate interaction with them by sharing the playing of the instrument, accompanying on other instruments, following their lead (e.g. imitating the rhythm), encouraging them to follow my lead, improvising lyrics to match with what they were playing (e.g. "Whee...and stop'), singing with patients playing familiar tunes, singing potentially familiar tunes (at times with the use of a song board chart), or responding to their playing in other ways (e.g. swaying). Patients had varied responses to my strategies. Sometimes they joined in and sang along as I matched their pitch (e.g. singing "la" to a scale the patient was playing on), made eye contact or left more musical space to show that they were aware I was musically imitating them, or demonstrated anticipation when I indicated I was about to stop (e.g. through varying pitch). Other times, patients responded indifferently to my strategies such as telling me to stop (e.g. "I only want to hear the bell sound"). Sometimes they had their own ideas and might request for us to explore with tempo for instance, learn something new, and I would go back to following their lead. For example, I invited one patient to pick a new piece for herself from the sheet music folder. We then shared the playing, with me playing the left-hand chordal accompaniment. At her request, I copied the sheet music for her use in future.

Sometimes, I facilitated patients to engage with other patients. Similar strategies included facilitating the interaction through sharing an instrument, negotiating turn-taking on instruments and verbally highlighting to patients' that others were enjoying their music. Once, as a patient sat by me and observed, I took the opportunity to invite him to take over my part. Though he was hesitant initially, I sang with both patients playing to support the interaction. Another time, when I shared that a younger patient was enjoying a patient's music, she seemed self-conscious and passed the instrument to me. I then imitated what the patient was doing earlier to continue highlighting that what she was playing previously was enjoyable. On the other hand, when I played instruments or introduced instruments to patients, they would usually interact with them. As I played familiar tunes on instruments, patients often accurately named the tune. Once, I offered a patient a xylophone and sung the respective colour for the patient to play on. The patient could then accurately guess 
the song she just played. Sometimes parents were surprised at what their children could do with musical instruments. When given an instrument to hold (which might be new to them), patients were able to explore and come up with creative ideas. One time, a patient fiddled with the tuning pegs of the guitar while watching a musical movie and I was able to join her on percussion instruments. Another time, the castanets were playfully used to grip on each other's shirts and coming into one another's personal space. While patients might not have been fully engaged in music making, the instruments created a connection between us.

A range of instruments could also be brought to patients' bedside. Sometimes sessions might start out as a 'jam', with parents joining in or leading. In one instance, the patient enjoyed this so much he started giving out instruments to others in the room and everyone joined in. I also used a song board chart which allowed patients to sing and play various instruments while I played accompaniment on guitar. We often explored instruments together. For example, with one patient, I named each instrument she picked up, in a sing-song manner. She imitated and matched the intonation in turn. In another session, a patient started making vocal sounds into the boomwhackers and I was able to imitate him. When patients were keeping a beat; shaking, drumming or bopping to music, I would begin to sing in time to their beat. Sometimes they would make a particular movement, and I would choose and offer them an instrument that they could sound by using that movement. Sometimes they would choose an instrument that would provoke me to sing a particular song, e.g. 'Jingle Bells'. In one instance when this happened, the patient didn't join in at the time, but each time the bells were introduced thereafter, she would sing it. Sometimes just giving a patient an instrument to hold would eventually lead to them playing it.

\section{Guitar}

When patients had prior musical experiences with the guitar, I would engage them with it. Due to the familiarity of the instrument, patients would start playing immediately. Sometimes I might recognize the short musical phrases patients were playing and hum or sing along. When I could not recognize what they were playing, I would ask. When requested, I would also teach patients how to play songs by going through the chord progression and strumming pattern. In one instance, when a patient seemed to have difficulty with certain aspects of the strumming pattern, I demonstrated it for him. The patient was then able to play more confidently (changing chords more 
smoothly and playing louder) and could come up with his own strumming pattern (double down strokes).

\section{Guitar/Ukulele}

Sometimes patients enjoyed pretending to be 'rock stars'. In this instance, I would facilitate their pretend play by allowing them to take turns in requesting songs which they would like to 'rock out' to or playing accompaniment on the beat. Boundaries had to be set to ensure instruments were not damaged during the 'rocking out' process.

Other times, patients' random strumming on the guitar or ukulele had contributed and motivated the patients to come up with their own song. As accompanying instruments, the guitar and ukulele were then used for notation and accompaniment for patients' song-writing. I would request patients to repeat their own composition a couple of times so I could figure out the chords/notes they were singing. I would also scribe or get the patients to write down the lyrics so that we could remember the words. Patients could also be taught how to play the root note (for example $\mathrm{C}$ on the ukulele) throughout their whole song as a means of resourcing so that they are able to play and perform their song while playing the base note. When playing the song together, I would add the chord progression to the patients' root note.

One time, a patient's playful encounter of exploring tuning pegs led to a discussion of feelings and how different sounds make us feel. While she initially requested for my input as to whether the sound sounded 'happy' or 'sad'; she soon managed to figure out that major keys were mostly associated with happy and minor keys were associated with sad.

\section{Boomwhackers}

When patients encountered the boomwhackers, I would encourage them to have a go. It was often creatively explored. Some patient-led exploration included pretend play (tubes as binoculars), tapping the tubes together, tapping against each other's tubes, tapping against other objects in the area, and vocalising through one end while placing the other against the ears. One time, I held three boomwhackers for a patient as he played a rhythmic pattern $(A, B, A, B, C, A, B, A, B, C)$. Occasionally, I might challenge patients by taking the lead but they would only mirror me at times. 


\section{Drums}

Patients sometimes presented their emotions clearly. To support patients' anger, I would allow them the autonomy and space to express themselves on the drum or sing in gentle tones after allowing space to help calm them down. For example, a patient who was seemingly angry as he banged against the walls was offered a drum to express and sound his anger instead.

\section{Singing}

In instances when patients were already singing, I would join in their singing. One time, I encouraged the patient to share variations of a song (The Maori and Dinosaur version of 'Twinkle Twinkle Little Star'). Other times, the frequent use of a song board chart listing potentially familiar songs was a good starting point for most patients as it encouraged them to make their own song choices. Patients did not always interact in expected ways. Sometimes patients would sing along, offer vocalisations, do the actions instead, offer gestures which could be adapted into the songs, or even played an accompanying instrument to the beat or shared one with me. Sometimes they would just listen. I would try to encourage patients' participation by, for example, leaving a space within the chorus for them to fill in the blanks or provide options of verses for them to choose from. Yet, patients sometimes still laughed before offering their choice or spoke the lyrics instead of singing it. Particularly with vocal sounds, I would echo back patients' vocal sounds which could lead to an improvisation. By doing so, patients were observed to be more vocal after the session.

Adapting potentially familiar songs was another key strategy in sustaining the group's attention because it encouraged choice-making and vocalisation. The use of dynamics could also invite for others in the room to join in singing. One time, I noticed a patient picking up on the repetitive phrase another patient was singing. I also had to be aware of the environment, taking into account patients' interest and their lead. Sometimes it was adapting patients' vocalisations into the music, their use of props, or inviting patients or siblings who had some skills to play accompaniment roles. Aside from patient- or family-led song choices, I also went with singing potentially familiar songs for the group at times. Once, a patient who was playing accompaniment for the group continued to strum a chord progression over and over. As I recognised another song that had the same chord progression, I started humming a new tune in which others joined in. 
Parents could also help make the connection between the patient and myself by joining in on the sing-along first, or taking the lead in sharing their child's song in individual or group settings. One time, I initiated interaction with a parent who was singing to her daughter in soft tones while rocking by coming in closer and joining in singing softly. Another time, one mother shared a bubble song which the rest of the group learnt.

\section{Utilizing Props}

Various props were used alongside music when interacting with patients, as they usually had toys at their bedside or were engaged in solitary play. To engage them, I would sing familiar songs or improvise lyrics to match with the prop or actions in which the patients were engaged with. For example, when a patient drew an apple on the chalkboard, I matched it with the song 'Apples and Bananas'. This prompted her to draw a banana afterwards and with the use of pauses and anacrusis within the song, I had the patient pointing to her 'apple' or 'banana' drawing. Another time, I made a sound effect "whee" while the patient dropped his blocks. He repeated the action and watched me react with another "whee" each time. Eventually, the patient repeated (with matching pitch) the sound effect for himself as he dropped his own blocks. The tapping of chalk (timbre) could be perceived as musical too and this once led to improvised chalk tapping in a turn-taking manner.

When patients were not engaged with their bedside resources, it was still a means of potentially knowing a child's interest. For example, a child who had a 'Wheels on the Bus' book was a cue for me to start singing the song. The child's mother then reiterated that it was patient's favourite song.

\section{Playing Musical Games}

Sometimes I would encourage patients to collaborate with me to invent and play musical games which would help us to get to know each other. The patients and I would often discuss and decide together what the rules and sequence of the game/s would be, and this would enable the patient to anticipate what was going to happen. For example, I facilitated the set-up of the 'Alphabet game'. We also had to negotiate and the patient suggested we shared a point when we had the same song on our lists. As part of the game and together with the play specialist, we engaged in a discussion of sharing songs on our individual lists in a turn-taking manner. The patient seemed 
confident in sharing her music in this manner and even sung snippets of the songs on her list with minimal prompting. With another patient, we used the iPad and played a game of 'Name That Song'.

Sometimes the range of instruments were adapted for musical games such as 'hide and seek' or 'stop and go'. For example, one patient wanted to play a 'hide and seek' game in her room. We decided that the drums would denote 'far' from hidden object and bells would denote 'closeness' to hidden object. At times, this was accompanied with dynamics (i.e. the louder the instrument meant the closer the seeker is to the hidden object). In subsequent music therapy sessions, patients always remembered the musical games we had played previously and would lead the musical game the way I had facilitated previously.

When I had a group of patients, I could introduce musical games such as the 'conducting' game. Having the 'conductor' role was empowering for patients and allowed me to be a participant or a guide for other patients who might need additional support during the game. One time, to guide the younger patient, I sang the rhythm for him to tap at the conductor's cue.

\section{Discussing Music}

Discussions were an important part of both individual and group sessions.

Discussions were sometimes used as a starting point when I had to engage patients at bedside. When I was trying to build a therapeutic relationship with patients, I sometimes had to ask them direct questions. Finding out what patients were interested in through direct questions would help me decide which instruments I might bring over or what we might potentially do for the music therapy session. I needed to know what songs they liked, because using music that we were both familiar with would build a connection between us. Once they had given me a clue about what they were interested in, I could talk to them about their music. Phrasing of questions were also important. For example, I asked a patient what her favourite song was and she said anything. However, when asked about her favourite band, she said 'Twenty One Pilots. It also allowed them to have a little more control - they could dictate the music - which was limited in their current situation. Once, I had a chat with a patient who had just finished watching a musical movie to find out if she had any favourite songs from the soundtrack already. Another time, I asked a patient regarding his experiences with 
music and I could build on what he knew by providing suggestions on what we could do in our session.

In instances where I was unfamiliar with patients' musical preferences, I would use technology to look up the song. Putting on familiar music would create a familiar environment. It was important for patients to know that I was interested in their music as well by giving them the 'expert role' as I asked questions about their music. Sometimes it also naturally opened discussion from the patient.

When parents were around, I would also ask them about their child's or the child's siblings' musical preferences in terms of both repertoire and instruments. For example, I was able to pass a patient her favourite instrument (ukulele) and she sat up when I did so. Another patient held the maracas, accompanied with singing of her favourite songs (as suggested by mom).

I would also encourage self-expression through song writing, and discussion would be an important part of this. Usually, the environment gave inspiration to patients. For example, other patients and siblings wiggling in the playroom reminded a patient of a worm and she went on to compose a song about worms. After coming up with original compositions, discussions sometimes involved encouragement on whether the composition should be extended, given a title, discussing what lyrics were about and the feasibility of performing for other patients.

Sometimes patients in an individual session were encouraged to invite and include others to form a group music session. For example, I encouraged a patient who was engaged in an individual session with me to play nursery rhymes to invite and include a younger patient that had just entered the playroom. The newly formed (mini) music group continued to expand afterwards. When groups were formed, we often had to negotiate which songs the group will sing next.

\section{Listening to Music}

When patients were engaged in other activities, I would sometimes offer for them to listen to music. Even in group settings, some patients and their parents might choose just to listen to the music. Sometimes they were seated as part of the music circle, but other times, they could be at the other end of the room and rocking to the music. While I would often invite patients and their parents to join the music circle, it did not matter if they declined. In that case, I would then occasionally make eye contact with patients and their families to still acknowledge them as part of the group. 
Additionally, hearing music from the ward corridors might pique other patients' interest and invite more people to the playroom.

\subsubsection{Wellbeing}

A couple of music therapy sessions had a family focus; where the sessions not only benefitted the patients, but also the family. It involved encouraging parents to take a break, supporting parents request as they went to check on the patient while leaving a sibling with me, including families in the music therapy sessions and supporting parents to leave the session for other reasons.

Moreover, relaxation in a hospital setting is important for pre-procedural support, post-procedural support or even well-being. This is so that patients may be composed when the procedure eventually takes place, or not associate the hospital with a traumatic event should they feel distressed after procedures.

Utilising what children would normally be engaged in outside of hospital is a facet of paediatric music therapy. This includes having autonomy and control. By requesting music and leading the sessions, patients were empowered.

\section{Playing Musical Instruments}

The instruments we engaged with would be patient-selected, and sometimes the role I played in the session depended on patients' choice for me as well. Other times, I might take up their lead by joining their exploration of the instrument or by accompanying on another instrument. I would also follow their verbal and musical cues. Some examples of musical cues were matching tempo and intensity, playing within the musical spaces in a turn-taking manner, or singing over their playing and following their pace. These strategies allowed patients' to feel 'heard' or complemented and they enjoyed being in control.

Resource booklets and sheet music were often used alongside instruments as well. For example, I sung the colour of the boomwhackers that the patient had to play to the tune of the song. Sometimes patients would request songs that I had no sheet music to and I would notate it for them for continued music making. Likewise, when patients or siblings had some musical skills on tunes instruments (keyboard, ukulele, etc.) and wanted to learn how to play a song, I would select appropriate (in line with skill level) sheet music or teach simple chords to play. Once I also observed and 
guided a patient when she requested for me to check her fingering while she played the guitar.

Parents were encouraged to join in when there were musical parts that were more than what patients' and I could manage independently. For example, when a patient was playing an ostinato part on the xylophone, his father and I played another ostinato part on the boomwhackers with vocal accompaniment.

Other times, instruments could be used to direct patients' attention away from what was happening around them. Many were drawn to reach out and play them independently. On one occasion when a dad was playing with a child, I helped a caregiver to take over by directing the child's attention to the chimes.

Especially with patients with special needs, the cabasa was a familiar instrument from school. One patient who recognised the instrument from school vocalised, stimulated by the sensory feedback she received from the instrument.

\section{Singing}

In family focused sessions, we always engaged in singing favourite songs. When parents were present, they were encouraged to join in the session. For example, a mother was able to join a session after encouragement to share nursery rhymes sung in the family's native language. This was a nice way for the parent and child to connect via music. When parents took a break and left patients and/or siblings with me, it seemed important that music, as a constant, kept going. I could do this by singing patients' selected songs, using the song board chart in a turn-taking manner (one line each) to encourage singing, or improvise singing to match what they were engaged in (e.g. playing with a toy chest of drawers). When patients and siblings joined in, I had an indication that they were comfortable in being left with me.

Singing is a part of daily life for some patients. Some had singing as a routine before bed while others sang whenever they were in the car, for example. Once, as I stroked a patient's palm in time with my singing, she fell asleep. On another occasion, I encouraged the child's father to bring the CD in the car up to the ward for continued sing-along. In addition to singing, we might tap, sway along or play instruments to the beat.

When I wanted to give patients autonomy and control, it was important to fully follow the patient's lead. This included singing the patient's requested song, keeping music going through continued sing-along or acknowledging any other request they 
might have. One time, a patient who was engaged in an art and craft activity requested for me to spell certain words out. I improvised her request by adapting it into a singsong form in which frustrated her and she told me to stop. I spelt it out for her in my talking voice instead. Another time, a patient requested 'Moana' on the iPad. I declined the use of the iPad as I knew how to play the song, and recreated the song with voice and guitar accompaniment. The patient seemed unconcerned but when I looked it up on the iPad afterwards, she smiled and enthusiastically joined in dancing in her chair and singing along.

\section{Utilizing Props}

While props such as a parachute may not be necessarily used outside of the hospital setting, the idea that it could bring a family together seemed important. Older siblings could play their role (in this instance, leading the play and deciding the actions) for the family group. Parents joined in and sung along. One time, to help pace the group, I sang over the families' voices.

With a patient with multiple disabilities, the use of sensory-based materials (such as a feather) swished in time to a hello song/nursery rhymes would stimulate her by providing tactile feedback. This would have been similar to activities she would have done in school.

In addition to bringing families together, props could also help in times of distress. The visual distraction of props, accompanied with familiar songs could calm patients down. For instance, patients being able to take deep enough breaths to join in singing about props or blowing bubbles were an indication that they were in a more relaxed and calm state.

\section{Playing Musical Games}

Playing games, such as 'conducting games', could provide patients with a sense of control even in individual settings. For example, a patient displayed enjoyment by indicating which instrument I should play and it continued for a long period of time. 


\section{Listening to Music}

Patients might be distressed when parents had to leave for a while to care for themselves. Thus, listening to soothing music could encourage calming movements for me to do with patients. One time, I supported a patient's mother to leave a patient with me while she took a break so that she would be more able to manage on her return. During this time, I danced with the child, bouncing and swaying to recorded music. This seemed to relax the patient.

Other times when patients were cuddled by parents, I would sit by them, playing quietly on accompanying instruments (such as the ukulele) humming nursery rhymes or improvising with my voice to encourage rocking and relaxation. If parents were already rocking, I would match my instrumental and vocal accompaniment to their rocking.

Occasionally, the accompanying instruments that I was playing might be attractive to patients and they would reach forward to play it. Accompanied with voice, I would place the instrument closer to patients for them to have a go while still maintaining the 'relaxed' action of rocking. Apart from encouraging rocking while seated, listening to music could also support other movements such as dancing. For example, to soothe a young patient who was fussing, I bounced and swayed her to recorded music.

Sometimes patients would request to listen to music while engaged in other activities such as art and crafts. Through the use of technology, patients could select the music; sometimes even from the suggestions lists to select the next song. When it was familiar to me, I would sing along. Though it was anticipated that patients would sing along to their selected music as well, sometimes they just listened. Other times we might sing along to the pre-recorded music together. 


\section{Clinical Vignette}

This clinical vignette illustrates music therapy with a patient I saw regularly during my placement.

Anna* (not her real name) is a seven-year-old girl. She was diagnosed with Cystic Fibrosis, a genetic disease, at the age of 15 months. Due to her condition, she has had developmental delays (delayed crawling and walking) and a mild weakness on one side. She is also on a high-calorie diet; required to take in one and a half times that of a typically developing child. Throughout the years, she has spent a lot of time at hospital and gets anxious as she associates the hospital and its staff with traumatic events. At present, she is admitted to the hospital every three months for a 'tune-up'; a preventive course of intravenous antibiotics and respiratory therapy.

Music therapy was used to support Anna in many ways, one of which being relaxation. It was important to work alongside other medical staff as pre-procedural support was necessary to ensure that Anna was calm before any procedure began. One time, as Anna was lying down, influenced by anaesthesia, I improvised and adapted familiar songs to the book she selected, 'Where's Wally'.

\section{Singing to the tune of 'Where is Thumbkin?'}

Me: Where is Wally, where is Wally, where are you?

Me: Here I am...Here I am...

(while pointing randomly to various images in the book which was not Wally)

This had Anna reacting by laughing at me identifying 'Wally' wrongly. Sometimes in between breathing in her medication, she would imitate and sing the adapted version with me. It was a sign that she was distracted, relaxed and engaged in the music and book; and less focused on what was medically happening to her.

Apart from medical staff, I also worked alongside her physiotherapist. As Anna's physiotherapy sessions were regular and rigorous, she sometimes lacked motivation or compliance as she might have found it boring, repetitive and hard work. However, when music and props were added, it motivated Anna to engage in movement. For example, the physiotherapist required Anna to jump on the trampoline. As I introduced a parachute which would naturally encourage jumping, we developed a musical game and supported with musical elements (e.g. dynamics, tempo, anacrusis) so that Anna could anticipate when to do certain actions such as a bigger 
jump. It likewise resourced the physiotherapist as well to engage in similar musical games to motivate Anna independently.

Music therapy has also helped Anna with her breathing and lung function. As she often has mucus build up in her chest, singing was utilized to improve her breathing and breath control. Through the use of a song board chart which had her favourite songs on them, we engaged in singing her selected song together. Sometimes I might play accompaniment while Anna played percussion instruments to the beat. At times, her mother joined in or led the singing to further encourage Anna to continue or join in singing with us. Particularly, 'silly' lyrics offered by Anna or myself were often utilized as it would make Anna laugh, which in turn would make her cough up her mucus. For example, "Old MacDonald had a cat-dog, E-I-E-I-E-O. With a meow-woof here and a meow-woof there...".

Music therapy was also a normalizing activity for Anna in that she could have social interaction with me or other patients, as she would with friends in school. One time, Anna requested for me to invite another patient, Charlie* (not her real name) whom she had met in a previous group music session, to the playroom. After we went over to Charlie's bed, I facilitated the mini group by requesting for the patients to share their music in a turn-taking manner (discussion). Even though Anna was unfamiliar with Charlie's music, she was observed to be smiling. This meant that Anna was receptive (listening) initially, in that it gave her a chance to listen and not sing and was interested in her friend's music. As Anna eventually imitated the lyrics she could pick up and started humming along to the tune afterwards, she became more actively involved in the music-making with Charlie. On the other hand, when it came to Anna's turn to share, she seemed hesitant. However, when I suggested a favourite song from individual music sessions, Charlie shared that she knew them as well and it boosted Anna's confidence. In subsequent group music sessions, Anna sometimes even requested for Charlie's music (songs that Charlie introduced previously).

Overall, music therapy has distracted and kept Anna calm during procedures, encouraged movement alongside her physiotherapy sessions, contributed towards her improved breathing, a means for social interaction and to have autonomy and control, especially in a setting where she lacked control. Music therapy was something she always looked forward to and wanted to engage with. The use of instruments, musical games, use of props and songs we sang were always patient-lead. While I would follow her lead, I often also build on her lead by engaging her in discussion in 
a group setting and listening to familiar or new repertoire to further encourage her to meet medical or music therapy goals. 


\section{Discussion}

In this section, I will address how some key findings link with the literature and highlight what I discovered out of my own practice. A section on the limitations of the research follows.

\section{Links to literature}

The findings were supported by the literature, i.e. 'chapter 2.3 Music therapy for children in hospitals' in that I engaged in active music therapy, utilized a wide range of instruments, used familiar songs, supported and included patients' families within sessions (family focus) and worked with props. This will be further discussed in the subsequent paragraphs.

There were numerous articles that cited the benefits and use of active music therapy with paediatric patients (Froehlich, 1996; Neugebauer \& Neugebauer, 2003; Standley \& Whipple, 2003; Turry, 2002). Based on my findings, I likewise frequently engaged children in active music therapy methods which involved using a range of instruments, props, engaging in musical games and singing. Action songs in particular were specifically used to encourage movement. However, when it came to the use of music therapy for procedural support, others have recommended improvisation (an active music therapy method) (Turry, 2002). In contrast, I found receptive listening to be more effective for the patients I was working with. Listening seemed to be more relaxing than engaging children in more active music making. Perhaps it matched the physical energy state the child was in (tired and unwell). It is likewise possible that this was related to my limited experience of working with children in this context. On the other hand, there were also instances when receptive listening led towards more active music making as patients might gradually join in singing along or the use of musical space from me encouraged a more active participation from the patient.

My findings highlighted the importance of being playful and flexible during music therapy sessions and especially with children. Parsiali (2012) mentioned that for the music therapist to incorporate child initiated playful ideas into musical play, the structure of sessions had to be flexible. For instance, patients could be engaged by the use of props and creative use of instruments which sometimes led to musical games. Bubble play could be accompanied with a bubble popping song and boomwhackers were used to explore vocal sounds. As props were clues to what 
children were interested in (Brooks \& O'Rourke, 2002), matching the music to what they were doing always had them responding and in turn, enabled us to build the therapeutic relationship. As suggested by Oldfield, Bell \& Pool (2012), the playful, nonverbal aspect of musical interactions between therapist and child played key roles in strengthening relationships. Moreover, the strategies highlighted in the findings such as placing instruments at strategic positions, lifting and playing instruments in front of the child, modelling how to play, inviting adults to play first in the hope that the child will join in afterwards were said to sustain the musical play and support communicative musical interactions (Parisali, 2012).

The use of familiar songs was likewise frequently cited in the literature (Brooks \& O’Rourke, 2002; Edwards, 1999; Hendon \& Bohon, 2008; Jarred, 2003; Lane, 1996; Neugebauer, 2012; Neugebauer \& Neugebauer, 2003; Stouffer and Shirk, 2003). While others have suggested that families were a means to find out patient-preferred music (Stouffer \& Shirk, 2003), my findings revealed other strategies for achieving this. Through discussion, sometimes patients and I came up with musical games such as 'name that tune' or identified song titles for each letter of the alphabet. Additionally, I often utilized interactive visual aids in my practice such as a song board chart and iPad which were also extremely useful for engaging patients. However, for the strategies I proposed, preferences could be misconstrued in that children might have picked songs they knew simply for the purpose of musical games or what they liked best from what was presented on the song board chart. However, it still provided a stepping stone in finding out patient-preferences as it allowed patients to have the autonomy and control without asking directly. It could also trigger and encourage verbalisation of patient's musical preferences afterwards.

A hallmark of music-centred music therapy is that music is central and a medium of experiences within therapeutic sessions (Aigen, 2005b). As participants of music therapy are primarily motivated to make music rather than achieve a nonmusical goal, verbal interactions in a music-centred music therapy approach are not considered necessary (Aigen, 2005b). However, "many music therapists define music therapy as the use of music to achieve non-musical goals" (Aigen, 2005b, p.66); and in this context, as in my work, verbal discussions are naturally employed. Some authors who support the use of verbal discussions during music therapy sessions include Borczon (2004), Lindblad (2016), and Nolan (2005). Lane (1996) also reiterated this by suggesting that patients are sometimes drawn to the therapist before 
the music, and as such verbal discussions were still considered to be a part of music therapy.

In a group setting, my findings described how at times I initiated singing potentially familiar songs for the group. Pavlicevic (2003) suggested that due to the semi-open nature of the group in a paediatric setting, it is important to manage the 'regular' members (patients who were familiar with the environment and me) and facilitate the inclusion of new members (patients who were recently admitted). Therefore, singing potentially familiar songs helped me manage the paediatric group, in that it connected people; the 'regular' members and the new members of the group.

The literature gave an overall overview of children's wellbeing in hospital, i.e. which gave them relief from hospital procedures and provided a sense of normalcy. As Stouffer \& Shirk (2003) had suggested, music is something that has positive connotations and connections for children, and which are not associated with medical procedures. However, music therapists do find ways to support specific medical goals such as breathing. My findings evidently suggest the use of singing to improve breathing. This was supported by Loewy (1999), Sliwka, Wloch, Tynor \& Nowobilski (2014), and Wade (2002), whose works have highlighted that asthmatic children had an increase and improvement in lung function after singing. Griggs-Drane (1999) further reiterated the effectiveness of music therapy interventions as equivalent to that of other traditional methods of treatment (the use of pulmonary devices); but that music therapy was more motivating due to the creative and social aspects of it. Additionally, the authors have also suggested other music therapy methods which I was unaware of: music listening for assisted breathing exercises and the use of wind instruments (Loewy, 1999; Sliwka et al., 2014; Wade, 2002). According to Griggs-Drane (1999), the respiratory benefits of playing musical wind instruments were that particular breathing techniques were required to sound the instruments.

\section{Terminologies}

I might have employed different terms to communicate my findings. For instance, what I often referred to as exploration of instruments might be referred to as a type of improvisation known as 'Nonreferential Improvisation'. This was defined by Bruscia (2013) as "the client improvises music for its own sake", where patients improvise on a musical instrument without reference to anything to make it represent or describe anything non-musical (p. 131). 
Additionally, musicking means to music, and defined as "...to take part, in any capacity, in a musical performance, whether by performing, by listening, by rehearsing or practising, by providing material for performance (what is called composing), or by dancing" (Small, 1998, p.9). Small (1998) refers to any activity that leads to (composing) or is part of a musical performance (performing, experiencing music) as an act of musicking. Moreover, he believes that everyone is capable of musicking as it includes activities that do not requiring any formal musical skills or training (Small, 1998). Campbell (2010) and Marsh (2008) further reiterated that musicking functions as a social action and everyday activity for children too. I was engaging paediatric patients in musicking as they read alphabetic sheet music or chose music from an IPad.

In my study, the goal 'encouraging social-interaction' referred to instances when music therapy was used to encourage social interaction between patients and me, as well as with others. The patients' engagement with me could be considered to be client-therapist relationship; which is defined as the feelings and attitudes that the therapist and client have toward one another and how these are expressed (Gelso \& Carter, 1994). Thus, some of the data in relation to 'social interaction' with me could have been illustrated as developing a therapeutic relationship instead.

Nevertheless, positive social interaction that occurs between a patient and music therapist is likely to be helpful in terms of supporting emotional wellbeing and wider socialisation (Lathom-Radocy, 2014). The term socialisation may be used to indicate efforts to develop the patients' potential to socialise and participate and communicate with others in group therapy. Lathom-Radocy (2014) suggested that music therapy may be conducted at the child's bedside initially, while group music therapy can be introduced in the later stages of recovery to improve social interaction. Lane (1996) supports this by highlighting that it was more important to proceed at a pace that is more comfortable for the patient.

\section{Limitations}

\section{Music therapy techniques}

While secondary analysis of data is a valid research approach, it has some limitations. Because the data was meant for other purposes other than this research (Coyer \& Gallo, 2005), it did not capture all of the aspects of my practice that I would 
have liked. For example, the music therapy techniques within the clinical notes and reflections I wrote as part of my usual music therapy work was not sufficient for me to do a micro-analysis of the multitude of music therapy techniques I might have utilized. Thus, I was only able to briefly suggest some techniques I had utilized within the music therapy sessions. A more experience practitioner and researcher may have produced more detailed notes and research findings.

That being said, the music therapy approach that I favoured would have also affected my clinical notes. As I consider myself to have adopted a humanistic music therapy approach, I tended to focus more on what was happening in the moment in terms of interpersonal communication (Bunt \& Stige, 2014). As a result, my notes described more about what happened between people more generally as opposed to what specifically happened in the music.

\section{Data analysis}

While the selected method for data analysis enabled findings to emerge, I wondered if sorting and viewing the data from a different angle would have led to a different set of findings. For instance, sorting data in terms of age-group instead of goals or primarily sorting data in terms of music therapy methods, strategies or techniques instead of goals. However, the current findings add valuable information to the existing knowledge base. 


\section{Conclusion}

This study answers the research question

'What music therapy methods, strategies and techniques did I use to engage children in meaningful music therapy encounters in hospital play therapy settings?'

The question came about as I initially found it challenging to engage patients in a play therapy setting. Through secondary and thematic analysis of clinical data, findings were obtained and presented in two sections. The first section identifies the predominant music therapy methods I utilized: a range of instruments, singing, use of props, listening, use of discussion and musical games. The second part of the findings further illustrates and expands on the music therapy methods, strategies and techniques and were presented through the goals I had for patients. Overall, engaging children in music therapy in a hospital setting involves taking a playful, flexible approach. Afterwards, I discussed the broader implications of the findings and limitations of this study. While the findings were mostly supported by the literature review, it also highlighted the importance of being playful and the necessary use of discussion during music therapy within a paediatric setting. My approach as a student music therapist and the methodology, i.e. secondary analysis of data, had an impact on the data and findings, and the terminology used. In conclusion, uncovering the music therapy methods, strategies and techniques I used to engage children in meaningful music therapy encounters in hospital play therapy settings gave me a better understanding of my work and is likely to add to the existing knowledge base for other practitioners in this setting. 


\section{References}

Aigen, K. (2005a). Being in music: Foundations of Nordoff-Robbins music therapy. Gilsum, NH: Barcelona Publishers.

Aigen, K. (2005b). Music-centered music therapy. Dallas, TX: Barcelona.

Amir, D. (1996). Experiencing music therapy: meaningful moments in the music therapy process. In M. Langenberg, K. Aigen, \& J. Frommer (Eds.). Qualitative Music Therapy Research: Beginning Dialogues. Gilsum, NH: Barcelona Publishers.

Ayson, C. (2008). Child-Parent Wellbeing in a Paediatric Ward: The Role of Music Therapy in Supporting Children and Their Parents Facing the Challenge of Hospitalisation. Voices: A World Forum for Music Therapy, 8(1). doi: 10.15845/voices.v8i1.449

Barnes, G. P. (2010). Moments of meeting: Difficulties and developments in shared attention, interaction, and communication with children with autism during two years of music therapy in a public preschool class (Order No. 3449507). Available from ProQuest Dissertations \& Theses Global. (862650757). Retrieved from https://search-proquestcom.helicon.vuw.ac.nz/docview/862650757?accountid=14782

Bishop, B., Christenberry, A., Robb, S., \& Rudenberg, M. (1996). Music therapy and child life interventions with pediatric burn patients. In M. A. Froehlich (Ed.), Music therapy with hospitalized children: A creative arts child life approach (pp. 87-108). Silver Spring, Md.: American Music Therapy Association.

Borczon, R. (2004). Music therapy: A fieldwork primer. Barcelona Publishers.

Bradt, J. (2012). Pain management with children. In J. Bradt (Ed.), Guidelines for music therapy practice in pediatric care (pp. 15-65). Retrieved from https://ebookcentral.proquest.com

Braun, V. \& Clarke, V. (2006). Using thematic analysis in psychology. Qualitative Research In Psychology, 3(2), pp. 77-101. doi:10.1191/1478088706qp063oa

Brooks, M., \& O'Rourke, A. (2002). Opening doors: music therapy in hospitals and hospices. Eastbourne, N.Z.: Wellington Society for Music Therapy.

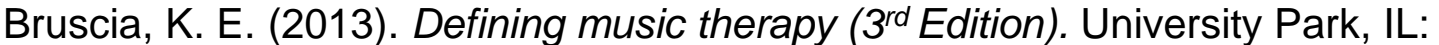
Barcelona Publishers.

Bunt, L., \& Stige, B. (2014). Music therapy: an art beyond words. New York: Routledge.

Campbell, D. A. (2007). Secondary Analysis. Orthopaedic Nursing, 26(4), pp. 241242. 
Campbell, P. (2010). Songs in their heads: Music and its meaning in children's lives. $\left(2^{\text {nd }}\right.$ Ed.). New York, NY: Oxford.

Craig, D. (2009). Exploring music preference: Meaningfulness of music as a function of emotional reactions. Nordic Journal of Music Therapy, 18(1), pp. 57-69.

Coyer, S., \& Gallo, A. (2005). Secondary analysis of data. Journal of Pediatric Health Care, 19(1), pp. 60-63. http://dx.doi.org/10.1016/j.pedhc.2004.10.003

Doverty, N. (1992). Therapeutic use of play in hospital. British Journal of Nursing, 1(2), pp. 79-81.

Edwards, J. (1999). Anxiety management in pediatric music therapy. In C. Dileo (Ed.), Music therapy \& medicine: Theoretical and clinical applications (pp. 6976). Silver Spring, Md.: American Music Therapy Association.

Encounter. 2017. In Merriam-Webster.com.Retrieved May 8, 2017, from https://www.merriam-webster.com/dictionary/encounter

Froehlich, M. (1996). Music therapy with hospitalized children: A creative arts child life approach. Cherry Hill, NJ: Jeffrey Books.

Gelso, C. \& Carter, J. (1994). Components of the psychotherapy relationship: Their interaction and unfolding during treatment. Journal of Counseling Psychology, 41(3), pp. 296-306.

Griggs-Drane, E. (1999). The use of musical wind instruments in the treatment of chronic pulmonary diseases. In C. Dileo (Ed.), Music therapy \& medicine: Theoretical and clinical applications (pp. 129-138). Silver Spring, Md.: American Music Therapy Association.

Hair, H. I. (1997). Divergent research in children's musical development. Psychomusicology: A Journal of Research in Music Cognition, 16(1-2), pp. 26-39. doi:10.1037/h0094069

Hendon, C., \& Bohon, L. M. (2008). Hospitalized children's mood differences during play and music therapy. Child: Care, Health \& Development, 34(2), pp. 141144. doi:10.1111/j.1365-2214.2007.00746.x

Izumi-Taylor, S., Gunn Morris, V., Meredith, C. D. ., \& Hicks, C. (2012). Music and Movement for Young Children's Healthy Development. Dimensions of Early Childhood, 40(2), pp. 33-40.

Jarred, J. (2003). Music assisted surgery: Preoperative and postoperative interventions. In S. L. Robb (Ed.), Music therapy in pediatric healthcare : Research and evidence-based practice (pp. 147-162). Silver Spring, Md.: American Music Therapy Association. 
Jun-Tai, N. (2008). Play in hospital. Paediatrics and Child Health, 18(5), pp. 233237. doi:10.1016/j.paed.2008.02.002

Kenny, C. (2007). Music, music therapy, musical encounters and world peace. Voices Resources. Retrieved from http://testvoices.uib.no.community/?q=colkenny12-2-7.

Kneisley, S. (1996). Therapeutic play in the hospital. In M. A. Froehlich (Ed.), Music therapy with hospitalized children: A creative arts child life approach (pp. 139148). Silver Spring, Md.: American Music Therapy Association.

Knight, S., \& Gregory, S. (2009). Specialising in play. Emergency Nurse, 16(10), pp. $16-19$.

Koops, L. (2012). 'Now can I watch my video?': Exploring musical play through video sharing and social networking in an early childhood music class. Research Studies in Music Education, 34(1), pp. 15-28.

Lane, D. (1996). Music therapy interventions with pediatric oncology patients. In M. A. Froehlich (Ed.), Music therapy with hospitalized children: A creative arts child life approach (pp. 109-116). Silver Spring, Md.: American Music Therapy Association.

Lapadat, J. (2012). Thematic analysis. In A. Mills, G. Durepos, \& E. Wiebe (Ed.), Encyclopedia of case study research (pp. 926-927). Thousand Oaks.: SAGE Publications, Inc.

Lathom-Radocy, W. B. (2014). Pediatric music therapy. Retrieved from https://ebookcentral.proquest.com

Lindblad, K. (2016). Verbal dialogue in music therapy: A hermeneutical analysis of three music therapy sessions. Voices: A World Forum For Music Therapy, 16(1). doi: 10.15845/voices.v16i1.842

Loewy, J. (1999). The use of music psychotherapy in the treatment of pediatric pain. In C. Dileo (Ed.), Music therapy \& medicine: Theoretical and clinical applications (pp. 189-206). Silver Spring, Md.: American Music Therapy Association.

Marley, L. (1996). Music therapy with hospitalized infants and toddlers in a child life program. In M. A. Froehlich (Ed.), Music therapy with hospitalized children: A creative arts child life approach (pp. 77-86). Silver Spring, Md.: American Music Therapy Association.

Marsh, K. (2008). The musical playground: Global tradition and change in children's songs and games. New York, NY: Oxford University Press.

Marsh, K., \& Young, S. (2006). Musical Play. The Child as Musician, pp. 289-310. doi:10.1093/acprof:oso/9780198530329.003.0015 
Meaningful. 2017. In Merriam-Webster.com.Retrieved May 8, 2017, from https://www.merriam-webster.com/dictionary/meaningful

Neugebauer, C. (2012). Children in general inpatient care. In J. Bradt (Ed.), Guidelines for music therapy practice in pediatric care (pp. 477-512). Retrieved from https://ebookcentral.proquest.com

Neugebauer, C. \& Neugebauer, V. (2003). Music therapy in pediatric burn care. In S. L. Robb (Ed.), Music therapy in pediatric healthcare : Research and evidencebased practice (pp. 31-48). Silver Spring, Md.: American Music Therapy Association.

Nolan, P. (2005). Verbal processing within the music therapy relationship. Music Therapy Perspectives, 23(1), pp. 18-28. Retrieved from https://searchproquest-com.helicon.vuw.ac.nz/docview/199501935?accountid=14782

New Zealand Society for Music Therapy. (2006). Code of Ethics for the practice of Music Therapy in New Zealand. New Zealand Society for Music Therapy.

Niland, A. (2009). The power of musical play: The value of play-based, childcentered curriculum in early childhood music education. General Music Today, 23(1), pp. 17-21.

Oldfield, A., Bell, K. \& Pool, J. (2012). Three families and three music therapists: Reflections on short term music therapy in child and family psychiatry. Nordic Journal of Music Therapy, 21(3), pp. 250-267.

Pasiali, V. (2012). Supporting parent-child interactions: Music therapy as an intervention for promoting mutually responsive orientation. Journal of Music Therapy, 49(3), pp. 303-334.

Pavlicevic, M. (2003). Groups in music: Strategies from music therapy. London: Jessica Kingsley Publishers.

Robb, S. (2003). Coping and chronic illness: Music therapy for children and adolescents with cancer. In S. L. Robb (Ed.), Music therapy in pediatric healthcare : Research and evidence-based practice (pp. 101-136). Silver Spring, Md.: American Music Therapy Association.

Shoemark, H., Rimmer, J., Bower, J., Tucquet, B., Miller, L., Fisher, M., Ogburn, N., Dun, B. (2018). A conceptual framework: The musical self as a unique pathway to outcomes in the acute pediatric health setting. Journal of Music Therapy, 55(1), 1-26. doi: 10.1093/jmt/thx018

Sliwka, A., Wloch, T., Tynor, D., \& Nowobilski, R. (2014). Do asthmatics benefit from music therapy? A systematic review. Complementary Therapies in Medicine, 22(4), 756-66.

doi:http://dx.doi.org.helicon.vuw.ac.nz/10.1016/j.ctim.2014.07.002 
Small, C. (2011). Musicking : the meanings of performing and listening. Retrieved from https://ebookcentral.proquest.com

Standley, J. \& Whipple, J. (2003). Music therapy with pediatric patients: A metaanalysis. In S. L. Robb (Ed.), Music therapy in pediatric healthcare : Research and evidence-based practice (pp. 1-18). Silver Spring, Md.: American Music Therapy Association.

Stouffer, J. \& Shirk, B. (2003). Critical care: Clinical applications of music for children on mechanical ventilation. In S. L. Robb (Ed.), Music therapy in pediatric healthcare : Research and evidence-based practice (pp. 49-80). Silver Spring, Md.: American Music Therapy Association.

Sundar, S., Ramesh, B., Dixit, P., Venkatesh, S., Das, P. and Gunasekaran, D. (2016). Live music therapy as an active focus of attention for pain and behavioral symptoms of distress during pediatric immunization. Clinical Pediatric, 55(8), pp. 745-748. doi: 10.1177/0009922815610613

Tarnowski, S.M. (1999). Musical play and young children. Music Educators Journal, 86(1), pp. 26-29.

Tucquet, B., \& Leung, M. (2014). Music therapy services in pediatric oncology. Journal of Pediatric Oncology Nursing, 31(6), 327-338. doi: $10.1177 / 1043454214533424$

Turry, A. (2002). A song of life: Improvised songs with children with cancer and serious blood disorders. In T. Wigram \& J. De Backer (Eds.), Clinical applications of music therapy in developmental disability, paediatrics, and neurology (pp. 13-31). London: Jessica Kingsley Publishers.

Victoria University of Wellington. (2016). Human ethics policy research policy group. Retrieved from http://www.victoria.ac.nz/documents/policy/researchpolicy/human-ethics-policy.pdf

Vijaya, M. (2014). Effectiveness of play therapy in reducing postoperative pain among children (2-5 yrs) in selected pediatric hospitals madurai. Asian Journal of Nursing Education and Research, 4(3), pp. 288-289. Retrieved from https://search-proquestcom.helicon.vuw.ac.nz/docview/1703573276?accountid=14782

Wade, L. (2002). A comparison of the effects of vocal exercises/singing versus music-assisted relaxation on peak expiratory flow rates of children with asthma. Music Therapy Perspectives, 20(1), pp.31-37.

Walworth, D. (2003). Procedural support: Music therapy assisted CT, EKG, EEG, Xray, IV, ventilator and emergency services. In S. L. Robb (Ed.), Music therapy in pediatric healthcare : Research and evidence-based practice (pp. 137146). Silver Spring, Md.: American Music Therapy Association. 


\section{Appendices}

\section{Appendix 1.1: Facility Information Sheet and Consent Form}

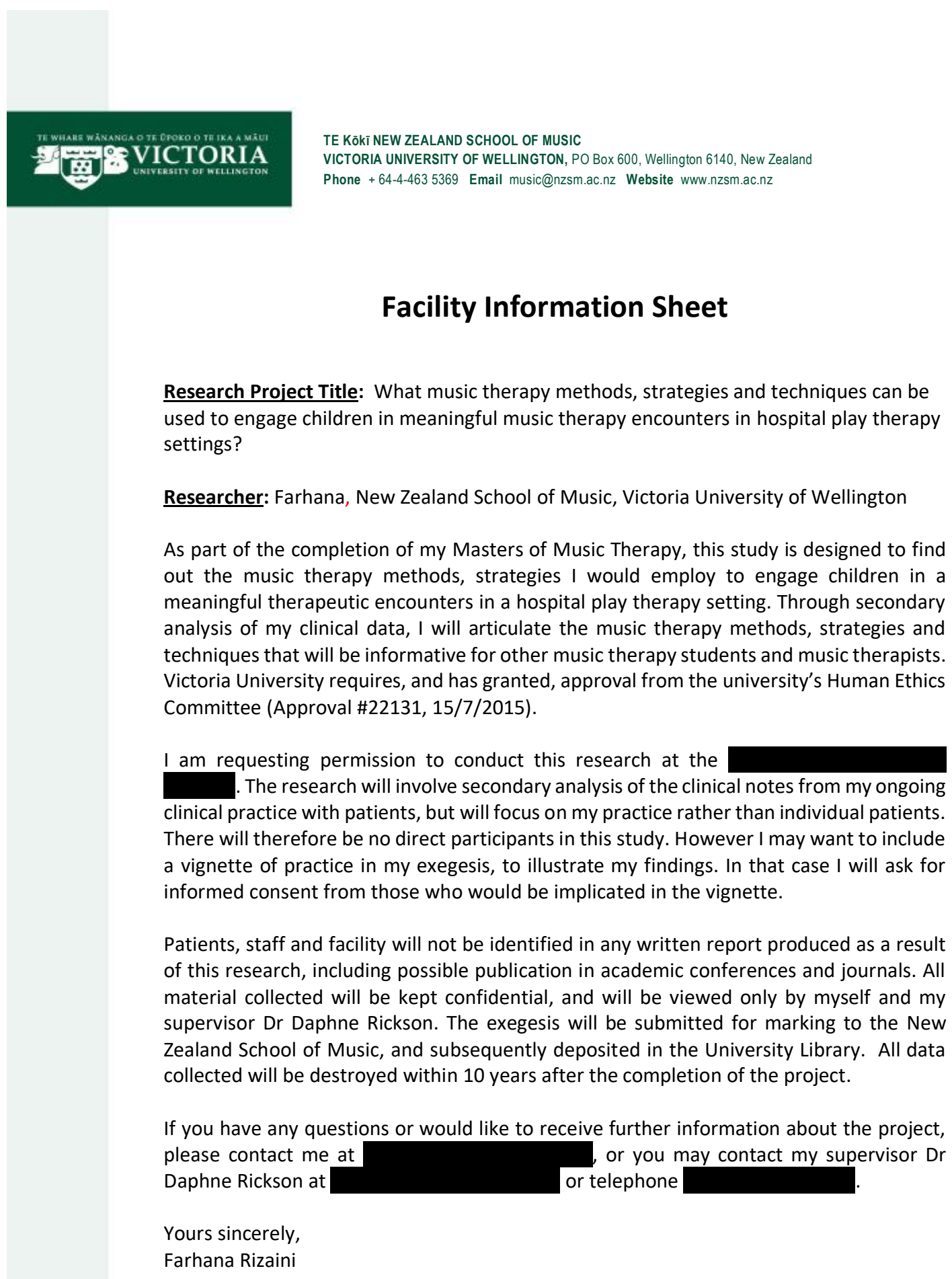




\section{Appendix 1.2: Facility Information Sheet and Consent Form}

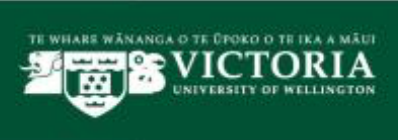

Study title:

Researcher:

Date:

TE KŌKİ NEW ZEALAND SCHOOL OF MUSIC

VICTORIA UNIVERSITY OF WELLINGTON, PO Box 600, Wellington 6140, New Zealand

Phone +64-4-463-5369 Email music@nzsm.ac.nz Web www.nzsm.ac.nz

\section{Consent Form}

1. I have read and I understand the Information Sheet relating to the above study.

2. I agree / do not agree that the study can be conducted in the

3. I know I can withdraw my consent before 31 $1^{\text {st }}$ July 2017.

4. I have a copy of the Information Sheet and Consent Form to keep. 


\section{Appendix 2.1: Clinical Vignette Information Sheet and Consent Form}

TE Kōkī NEW ZEALAND SCHOOL OF MUSIC

VICTORIA UNIVERSITY OF WELLINGTON, PO Box 600, Wellington 6140, New Zealand

Phone +64-4-4635369 Email music@nzsm.ac.nz Website www.nzsm.ac.nz

\section{Participant Information Sheet (Vignette)}

Research Project Title: What music therapy methods, strategies and techniques can be used to engage children in meaningful music therapy encounters in hospital play therapy settings?

\section{Researcher: Farhana, New Zealand School of Music, Victoria University of Wellington}

As part of the completion of my Masters of Music Therapy, this study is designed to find out the music therapy methods, strategies I would employ to engage children in a meaningful therapeutic encounters in a hospital play therapy setting. Through secondary analysis of my clinical data, I will articulate the music therapy methods, strategies and techniques that will be informative for other music therapy students and music therapists. Victoria University requires, and has granted, approval from the university's Human Ethics Committee (Approval \#22131, 15/7/2015).

The research will involve secondary analysis of the clinical notes from my ongoing clinical practice with patients, but will focus on my practice rather than individual patients. There will therefore be no direct participants in this study. However, I would like to include a vignette of practice in my exegesis, to illustrate my findings.

I am requesting for your permission to describe the work I have been doing with $\square$ in a vignette. will not be identified personally in any written report produced as a result of this research, including possible publication in academic conferences and journals. All information collected will be kept confidential, and will be viewed only by myself and my supervisor Dr Daphne Rickson. The exegesis will be submitted for marking to the New Zealand School of Music, and subsequently deposited in the University Library. In line with the Hospital's and University's policy, all data collected will be destroyed within 10 years after the completion of the project.

If you have any questions or would like to receive further information about the project, please contact me at Dr Daphne Rickson at or you may contact my supervisor or telephone

Yours sincerely,

Farhana Rizaini 


\title{
Appendix 2.2: Clinical Vignette Information Sheet and Consent Form
}

\author{
TE KŌKĪ NEW ZEALAND SCHOOL OF MUSIC \\ VICTORIA UNIVERSITY OF WELLINGTON, PO Box 600, Wellington 6140, New Zealand \\ Phone +64-4-463-5369 Email music@nzsm.ac.nz Web www.nzsm.ac.nz
}

\section{Consent Form}

1. I have read and I understand the Information Sheet relating to the above study.

2. I give informed consent for

to be a participant in this study.

3. I know I can withdraw my consent before 31 ${ }^{\text {st }}$ July 2017.

4. I have a copy of the Information Sheet and Consent Form to keep.

Parent/Guardian Signature:

Date:

Facility Representative Signature:
Date: 
Appendix 3.1: Illustration of Methodology-Example of Clinical Notes

Music Therapy Note

Name:

Age:

Diagnosis:
Date: 24 May 2017

Location: Bedside

Time: About 45 minutes

\section{Initial Behaviours:}

was comfortably lying down in bed. Her grandparents were with her. When I offered music, the grandparents took the opportunity to have breakfast downstairs.

Goal: Encourage movement

\section{Overview of Music Therapy Session:}

I brought over a lollipop drum, chimes, tambourine, shaker, wrist bells and a ukulele. To start off, I placed the wrist bells on left wrist and sang a 'hello' song while holding her hand and moving to the beat. She smiled and maintained eye contact. I picked up the ukulele and sang some of her favourite nursery rhymes- 'five little monkeys', 'old macdonald had a farm, etc. For songs with actions, 'itsy bitsy spider', 'mr. sun', I did finger play which observed and smiled. She responded to me using dynamics and tempo and would chuckle. Though she rarely moved her arms/bells, her smiles and vocal sounds "Ahhhh" kept coming.

Thereafter, I played with the shaker; moving it up and down, side to side and tapping on her body parts. The up and down and side to side motion was accompanied by a vocal glissando. tracked the shaker and gave a chuckle at the end of every glissando. We repeated the shaker and glissando a few times before I introduced the lollipop drum and tambourine to her. I gently tapped the drum/tambourine against her clenched fist and sang 'Aiken Drum' which had a ti-ti-ta rhythm. When I stopped tapping the tambourine/drum against her, $\square$ did not reach out for the instruments.

To encourage to move her arms, I decided to utilize the chimes next. I sang 'twinkle twinkle' while demonstrating and placing the chimes closer to either side of her hands. Gradually, reached out independently and touched the chimes! I encouraged her by singing "Yay Mila" and she repeated her movement with more force (chimes were played louder). Periodically, her legs would start kicking as well.

This led me to do more movement with her through holding her hands. We rowed for 'row row row your boat' and did various actions for 'wheels on the bus'. As her fingers were still in a ball, I held her wrist initially till — eventually uncurled her fingers and had a strong grip on mine.

\section{Comments:}

- was generous with her smiles, chuckles and vocal sounds throughout the session. She was engaged and continues to demonstrate her love for music through her long attention span. Her kicking at times could also mean that she was excited. 
- Her ability to track what I'm doing and responding to the musical elements such as tempo and dynamics meant that she was aware of what was happening.

- Chimes motivated to play it independently. When I held her hands to do more movement thereafter, she didn't seem to mind, eventually uncurling it.

- I would perhaps try doing movement first before introducing instruments to her next time to bring awareness to her arms and fingers. Perhaps by doing so, it might encourage to move more independently to play the instruments. 
Appendix 3.2: Illustration of Methodology-Example of Clinical Note to Excel Sheet

\begin{tabular}{|c|c|c|c|c|c|c|}
\hline$\underline{\text { Date }}$ & Context & Goals & Methods & Strategy & Techniques & Notes \\
\hline $\mathrm{CN} .24 .05 .01$ & $\begin{array}{l}\text { has } \quad \text { Was } \\
\text { comfortable in bed but } \\
\text { needed exercise }\end{array}$ & Encourage movement & Instruments (range) & $\begin{array}{l}\text { Accessibility (ensuring ease of } \\
\text { access and sounding through } \\
\text { choice of instrument) }\end{array}$ & $\begin{array}{l}\text { Place the bells on patient's } \\
\text { wrist }\end{array}$ & \\
\hline CN.24.05.01 & $\begin{array}{l}\text { has Was } \\
\text { comfortable in bed but } \\
\text { needed exercise }\end{array}$ & Encourage movement & Instruments (range) & $\begin{array}{l}\text { Accompaniment with voice to } \\
\text { enhance motivation }\end{array}$ & Sang a greeting song & \\
\hline CN.24.05.01 & $\begin{array}{l}\text { has Was } \\
\text { comfortable in bed but } \\
\text { needed exercise }\end{array}$ & Encourage movement & Instruments (range) & Movement (facilitated) & $\begin{array}{l}\text { Held her hand and supported } \\
\text { her movement to sound the } \\
\text { bells }\end{array}$ & \\
\hline CN.24.05.01 & $\begin{array}{l}\text { has } \text { Was } \\
\text { comfortable in bed but } \\
\text { needed exercise }\end{array}$ & Encourage movement & Instruments (range) & $\begin{array}{l}\text { Accompaniment with Ukulele and } \\
\text { Voice }\end{array}$ & & \\
\hline $\mathrm{CN} .24 .05 .01$ & $\begin{array}{l}\text { has Was } \\
\text { comfortable in bed but } \\
\text { needed exercise }\end{array}$ & Encourage movement & Instruments (range) & Repertoire (favourite songs) & Nursery rhymes with actions & $\begin{array}{l}\text { Rarely moved her arms/ bells } \\
\text { but smiles and vocal sounds } \\
\text { "Abah" kept coming. }\end{array}$ \\
\hline CN.24.05.01 & $\begin{array}{l}\text { has Was } \\
\text { comfortable in bed but } \\
\text { needed exercise }\end{array}$ & Encourage movement & Instruments (range) & $\begin{array}{l}\text { Repertoire (action songs to } \\
\text { encourage her to move which in } \\
\text { turn would sound the instrument) }\end{array}$ & $\begin{array}{l}\text { Patient observed me doing } \\
\text { finger play to action songs } \\
\text { and smiled. }\end{array}$ & \\
\hline $\mathrm{CN} .24 .05 .01$ & $\begin{array}{l}\text { has Was } \\
\text { comfortable in bed but } \\
\text { needed exercise }\end{array}$ & Encourage movement & Instruments (range) & Musical elements & $\begin{array}{l}\text { Use of dynamics and tempo } \\
\text { within action songs. Patient } \\
\text { responded with a chuckle. }\end{array}$ & \\
\hline CN.24.05.01 & $\begin{array}{l}\text { has } \text { Was } \\
\text { comfortable in bed but } \\
\text { needed exercise }\end{array}$ & Encourage movement & Instruments (range) & Accompaniment with shaker & $\begin{array}{l}\text { Directional movement (moving } \\
\text { it up and down, side to side) }\end{array}$ & $\begin{array}{l}\text { tracked the shaker and } \\
\text { gave a chuckle at the end of } \\
\text { every glissando. }\end{array}$ \\
\hline $\mathrm{CN} .24 .05 .01$ & $\begin{array}{l}\text { has } \text { Was } \\
\text { comfortable in bed but } \\
\text { needed exercise }\end{array}$ & Encourage movement & Instruments (range) & $\begin{array}{l}\text { Accompaniment with shaker and } \\
\text { vocal glissando }\end{array}$ & $\begin{array}{l}\text { Tactile feedback (tapping on } \\
\text { her body parts). }\end{array}$ & $\begin{array}{l}\text { I gently tapped the } \\
\text { drum/tambourine against her } \\
\text { clenched fist and sang 'Aiken } \\
\text { Drum' which had a ti-ti-ta } \\
\text { thythm. }\end{array}$ \\
\hline $\mathrm{CN} .24 .05 .01$ & $\begin{array}{l}\text { has } \text { Was } \\
\text { comfortable in bed but } \\
\text { needed exercise }\end{array}$ & Encourage movement & Instruments (range) & $\begin{array}{l}\text { Sharing the playing of the } \\
\text { instrument }\end{array}$ & $\begin{array}{l}\text { Tapping instruments gently } \\
\text { against patient to facilitate } \\
\text { body awareness through } \\
\text { 'shared' playing }\end{array}$ & $\begin{array}{l}\text { Gradually reached out and } \\
\text { independently touched the } \\
\text { chimes. I praised the patient } \\
\text { and she repeated with more } \\
\text { force (chimes played louder). } \\
\text { Periodically, legs would start } \\
\text { kicking as well. }\end{array}$ \\
\hline CN.24.05.01 & $\begin{array}{l}\text { has } \text { Was } \\
\text { comfortable in bed but } \\
\text { needed exercise }\end{array}$ & Encourage movement & $\begin{array}{l}\text { Instruments } \\
\text { (chimes) }\end{array}$ & Accompaniment with voice & $\begin{array}{l}\text { Singing while demonstrating } \\
\text { and placing the chimes closer } \\
\text { to either side of patient's } \\
\text { hands. }\end{array}$ & $\begin{array}{l}\text { Patient had her fingers in a } \\
\text { clench initially and I held her } \\
\text { wrist till she uncurled and had } \\
\text { a strong grip on my hands. }\end{array}$ \\
\hline CN.24.05.01 & $\begin{array}{l}\text { has } \text { Was } \\
\text { comfortable in bed but } \\
\text { needed exercise }\end{array}$ & Encourage movement & Movement & Holding hands & $\begin{array}{l}\text { Facilitated movement in a } \\
\text { rowing motion for 'row tow } \\
\text { row your boat' and actions for } \\
\text { wheels on the bus'. }\end{array}$ & \\
\hline
\end{tabular}


Appendix 4: Illustration of Methodology -Extract from Excel Sheet

When all the data had been coded into excel, the data were sorted according to goals, followed by methods. A new column known as 'Initial Findings' was later expanded on within the findings section of this study.

\begin{tabular}{|c|c|c|c|c|c|c|c|}
\hline Date & Context & Goals & Methods & Strategy & Techniques & Notes & $\underline{\text { Initial Findings }}$ \\
\hline $\begin{array}{l}\text { CN.26.04. } \\
01\end{array}$ & $\begin{array}{l}\text { and I moved on } \\
\text { from the guitar }\end{array}$ & $\begin{array}{l}\text { Building } \\
\text { therapeutic } \\
\text { relationship }\end{array}$ & $\begin{array}{l}\text { Making up and } \\
\text { playing musical } \\
\text { games together }\end{array}$ & $\begin{array}{l}\text { Technology } \\
\text { (lpad) }\end{array}$ & $\begin{array}{l}\text { Playing a game of } \\
\text { 'Name that song' }\end{array}$ & $\begin{array}{l}\text { Getting to know one } \\
\text { another better } \\
\text { through song } \\
\text { sharing }\end{array}$ & \multirow{5}{*}{$\begin{array}{l}\text { Sometimes I would enoourage a } \\
\text { patient to collaborate with me to invent } \\
\text { and play musical games which would } \\
\text { help us to get to know each other. For } \\
\text { examole...facilitating the set ug of the } \\
\text { 'Alphabet game' where the patient had } \\
\text { a say in the play rules. }\end{array}$} \\
\hline $\begin{array}{l}\text { CN.02.05. } \\
02\end{array}$ & $\begin{array}{l}\text { Shas requested } \\
\text { to play alphabet music } \\
\text { game. }\end{array}$ & $\begin{array}{l}\text { Building } \\
\text { therapeutic } \\
\text { relationship }\end{array}$ & $\begin{array}{l}\text { Making up and } \\
\text { playing musical } \\
\text { games together }\end{array}$ & Discussion & $\begin{array}{l}\text { Facilitated sharing } \\
\text { through turn-taking of } \\
\text { songs on each } \\
\text { individuals' list. }\end{array}$ & $\begin{array}{l}\text { Patient oommented } \\
\text { that one of the HPS } \\
\text { songs were old and } \\
\text { giggled. Patient } \\
\text { seemed more } \\
\text { confident in sharing. }\end{array}$ & \\
\hline $\begin{array}{l}\text { CN.02.05. } \\
02\end{array}$ & $\begin{array}{l}\text { man has } \\
\text { She requested } \\
\text { to play alphabet music } \\
\text { game. }\end{array}$ & $\begin{array}{l}\text { Building } \\
\text { therapeutic } \\
\text { relationship }\end{array}$ & $\begin{array}{l}\text { Making up and } \\
\text { playing musical } \\
\text { games together }\end{array}$ & Negotiating & $\begin{array}{l}\text { Patient suggested we } \\
\text { shared a point when we } \\
\text { had the same answer. I } \\
\text { went with her request. }\end{array}$ & & \\
\hline $\begin{array}{l}\text { CN.02.05. } \\
02\end{array}$ & $\begin{array}{l}\text { mas } \\
\text { She requested } \\
\text { to play alphabet music } \\
\text { game. }\end{array}$ & $\begin{array}{l}\text { Building } \\
\text { therapeutic } \\
\text { relationship }\end{array}$ & Singing & Game & $\begin{array}{l}\text { Play rules involved } \\
\text { singing a snippet of the } \\
\text { songs on list }\end{array}$ & $\begin{array}{l}\text { Patient did this with } \\
\text { minimal prompting. } \\
\text { Took lead at times. }\end{array}$ & \\
\hline $\begin{array}{l}\text { CN.02.05. } \\
02\end{array}$ & $\begin{array}{l}\text { man } \\
\text { She requested } \\
\text { to play alphabet music } \\
\text { game. }\end{array}$ & $\begin{array}{l}\text { Building } \\
\text { therapeutic } \\
\text { relationship }\end{array}$ & Game & Play rules & $\begin{array}{l}\text { Facilitated the setting } \\
\text { up of the alphabet } \\
\text { game. }\end{array}$ & HPS, me, patient. & \\
\hline $\begin{array}{l}\text { CN.08.05. } \\
02\end{array}$ & $\begin{array}{l}\text { She was } \\
\text { doing paper maghe, in } \\
\text { the playroom. Minder } \\
\text { requested if I had more } \\
\text { current songs } \\
\text { compared to a } \\
\text { children's one playing in } \\
\text { the background. }\end{array}$ & $\begin{array}{l}\text { Building } \\
\text { therapeutic } \\
\text { relationship }\end{array}$ & Discussion & $\begin{array}{l}\text { Repertoire- } \\
\text { choosing } \\
\text { familiar song }\end{array}$ & $\begin{array}{l}\text { Asking patient what her } \\
\text { favourite song was } \\
\text { "anything" Asking } \\
\text { patient what her } \\
\text { favourite band was "21 } \\
\text { pilots" }\end{array}$ & $\begin{array}{l}\text { Putting on familiar } \\
\text { music to create a } \\
\text { familiar } \\
\text { environment. }\end{array}$ & \multirow{2}{*}{$\begin{array}{l}\text { When I was trying to build a } \\
\text { therapeutic relationship with patients, I } \\
\text { sometimes had to ask them direct } \\
\text { questions. I needed to know what } \\
\text { songs they liked, because using music } \\
\text { that we were both familiar with would } \\
\text { build a connection between us. It also } \\
\text { helped them to have a little more } \\
\text { control - they could dictate the music - } \\
\text { which was limited in their current } \\
\text { situation. Once they had given me a } \\
\text { clue about what they were interested in }\end{array}$} \\
\hline $\begin{array}{l}\text { CN.08.05. } \\
02\end{array}$ & $\begin{array}{l}\text { She was } \\
\text { doing paper machat in }\end{array}$ & $\begin{array}{l}\text { Building } \\
\text { therapeutic } \\
\text { relationship }\end{array}$ & Discussion & $\begin{array}{l}\text { technology } \\
\text { (lpad) }\end{array}$ & $\begin{array}{l}\text { Looking up '21 pilot's } \\
\text { music playlist and it } \\
\text { opened up discussion }\end{array}$ & $\begin{array}{l}\text { Patient didn't sing } \\
\text { along but I noticed } \\
\text { her glancing and }\end{array}$ & \\
\hline
\end{tabular}




\begin{tabular}{|c|c|c|c|c|c|c|c|}
\hline & $\begin{array}{l}\text { the playroom. Minder } \\
\text { requested if I had more } \\
\text { current songs } \\
\text { compared to a } \\
\text { children's one playing in } \\
\text { the background. }\end{array}$ & & & & $\begin{array}{l}\text { about how she went for } \\
\text { their concert }\end{array}$ & $\begin{array}{l}\text { looking at the music } \\
\text { video from time to } \\
\text { time. }\end{array}$ & \multirow{5}{*}{$\begin{array}{l}\text { I could talk to them about their music. } \\
\text { For examcle... ( } 21 \text { pilot's...). Twice I } \\
\text { also had a chat with parents to find out } \\
\text { siblingsipatients' favourite instrument's } \\
\text { and songs. As the patient held the } \\
\text { maracas (known favourite) } \\
\text { acoompanied with singing of her } \\
\text { favourite songs, mom guided her } \\
\text { child's hand by moving them and her to } \\
\text { the beat and singing along. }\end{array}$} \\
\hline $\begin{array}{l}\text { CN.08.05. } \\
02\end{array}$ & $\begin{array}{l}\text { She was } \\
\text { doing paner maghe, in } \\
\text { the playroom. Minder } \\
\text { requested if I had more } \\
\text { current songs } \\
\text { compared to a } \\
\text { children's one playing in } \\
\text { the background. }\end{array}$ & $\begin{array}{l}\text { Building } \\
\text { therapeutic } \\
\text { relationship }\end{array}$ & Discussion & Questions & $\begin{array}{l}\text { Asked questions about } \\
\text { the band and slight } \\
\text { discussion about the } \\
\text { music video }\end{array}$ & $\begin{array}{l}\text { Gave patient the } \\
\text { opportunity to take } \\
\text { the "expert role" as } \\
\text { band and its music } \\
\text { was unfamiliar for } \\
\text { me }\end{array}$ & \\
\hline $\begin{array}{l}\text { CN.24.04. } \\
04\end{array}$ & $\begin{array}{l}\text { Patient's sibling was } \\
\text { playing in the playroom. }\end{array}$ & $\begin{array}{l}\text { Building } \\
\text { therapeutic } \\
\text { relationship }\end{array}$ & Discussion & $\begin{array}{l}\text { Repertoire- } \\
\text { favourite } \\
\text { songs }\end{array}$ & $\begin{array}{l}\text { Had a chat with mom } \\
\text { who shared sibling's } \\
\text { favourite } \\
\text { instruments/songs }\end{array}$ & & \\
\hline $\begin{array}{l}\text { CN.24.04. } \\
04\end{array}$ & $\begin{array}{l}\text { Patient's sibling was } \\
\text { playing in the playroom. }\end{array}$ & $\begin{array}{l}\text { Building } \\
\text { therapeutic } \\
\text { relationship }\end{array}$ & $\begin{array}{l}\text { Instruments } \\
\text { (maracas) }\end{array}$ & $\begin{array}{l}\text { Repertoire- } \\
\text { favourite } \\
\text { songs }\end{array}$ & $\begin{array}{l}\text { Accompaniment with } \\
\text { voice }\end{array}$ & $\begin{array}{l}\text { Mom was holding } \\
\text { sister's hands and } \\
\text { singing along and } \\
\text { moving the sister to } \\
\text { the beat. }\end{array}$ & \\
\hline $\begin{array}{l}\text { CN.24.04. } \\
01\end{array}$ & $\begin{array}{l}\text { has a } \\
\text { She was } \\
\text { playing with the } \\
\text { xylophone while seated } \\
\text { on the sofa. }\end{array}$ & $\begin{array}{l}\text { Building } \\
\text { therapeutic } \\
\text { relationship }\end{array}$ & Discussion & Questions & $\begin{array}{l}\text { Had a chat with parents } \\
\text { whom shared that } \\
\text { is familiar with } \\
\text { the ukulele. } \\
\text { up when I passed her } \\
\text { the ukulele. }\end{array}$ & & \\
\hline $\begin{array}{l}\text { CN.29.05. } \\
01\end{array}$ & $\begin{array}{l}\text { She was } \\
\text { cuddling with mom in } \\
\text { bed. Mom shared that } \\
\text { they were doing } \\
\text { singing. }\end{array}$ & $\begin{array}{l}\text { Building } \\
\text { therapeutic } \\
\text { relationship }\end{array}$ & Singing & Repertoire & $\begin{array}{l}\text { Following mom's lead } \\
\text { of song choices and } \\
\text { singing in soft tones } \\
\text { while rocking } \\
\text { came closer and joined } \\
\text { in singing quietly. }\end{array}$ & $\begin{array}{l}\text { turned to look } \\
\text { at me and mom } \\
\text { adjusted her. } \\
\text { Smiled and made } \\
\text { eye contact with } \\
\text { mom and myself. }\end{array}$ & $\begin{array}{l}\text { If a parent is around, they are a means } \\
\text { of collaboration as well to find out their } \\
\text { child's musical preferences. }\end{array}$ \\
\hline
\end{tabular}

